\title{
MCDM Assessment of a Healthy and Safe Built Environment According to Sustainable Development Principles: A Practical Neighborhood Approach in Vilnius
}

\author{
Edmundas Kazimieras Zavadskas ${ }^{1}$, Fausto Cavallaro ${ }^{2, *}$, Valentinas Podvezko ${ }^{3}$, Ieva Ubarte ${ }^{4}$ \\ and Arturas Kaklauskas ${ }^{5}$ \\ 1 Department of Construction Technology and Management, Sauletekis ave.11, Vilnius LT-10223, Lithuania; \\ edmundas.zavadskas@vgtu.lt \\ 2 Department of Economics, Management, Society and Institutions (EGSI), University of Molise, \\ Via De Sanctis, Campobasso 86100, Italy \\ 3 Department of Mathematical Statistics, Sauletekis ave.11, Vilnius LT-10223, Lithuania; \\ valentinas.podvezko@vgtu.lt \\ 4 Research Institute of Smart Building Technologies, Sauletekis ave.11, Vilnius LT-10223, Lithuania; \\ ieva.ubarte@vgtu.lt \\ 5 Department of Construction Economics and Property Management, Sauletekis ave.11, Vilnius LT-10223, \\ Lithuania; arturas.kaklauskas@vgtu.lt \\ * Correspondence: cavallaro@unimol.it; Tel.: +39-0874-404428
}

Academic Editor: Paul Burger

Received: 23 February 2017; Accepted: 25 April 2017; Published: 28 April 2017

\begin{abstract}
Urbanization has a massive effect on the environment, both locally and globally. With an ever-increasing scale of construction and manufacturing and misuse of energy resources come poorer air quality, growing mortality rates and more rapid climate change. For these reasons, a healthy and safe built environment is ever more in demand. Global debates focus on sustainable development of the built environment; a rational approach to its analysis is multiple criteria decision making (MCDM) methods. Alternative MCDM methods applied to the same problem often produce different results. In the search for a more reliable tool, this study proposes that a system of MCDM methods should be applied to a single problem. This article assesses 21 neighborhoods in Vilnius in the context of a healthy and safe built environment in view of the principles of sustainable development. MCDM methods were used for this purpose: entropy, Criterion Impact LOSs (CILOS) and Integrated Determination of Objective Criteria Weights (IDOCRIW) methods were used to determine the objective weights of the criteria, while expert judgement determined the subjective weights. With the overall weights determined, the Vilnius neighborhoods were assessed through the application of COmplex PRoportional ASsessment (COPRAS), Simple Additive Weighting (SAW), Technique for Order of Preference by Similarity to Ideal Solution (TOPSIS) and Evaluation based on Distance from Average Solution (EDAS) methods. The final results were then processed using the rank average method, Borda count and Copeland's method.
\end{abstract}

Keywords: healthy and safe built environment; sustainable development; MCDM methods; neighborhoods; Vilnius

\section{Introduction}

The built environment is responsible for significant use of final energy $(62 \%)$ and is a major source of greenhouse gas emissions (55\%) [1]. According to Joffe and Smith [2], cities contribute the vast 
majority of emissions, and a growing proportion of the world's population lives in cities. With the ever-increasing scale of construction and manufacturing and misuse of energy resources come poorer air quality, growing mortality rates, more rapid climate change and other issues. Many scientists look at a healthy and safe environment in terms of land use, transport, architectural design policies and strategies, strategic planning, collaborative design, etc. [2-6]. Sallis et al. [3] argue that there is growing evidence suggesting that healthy urban design and transport policies can have benefits beyond health for environmental sustainability and economic vitality. An article by Mohtashami et al. [4] determines policies and strategies for the architectural design of healthy buildings according to the health and safety conditions that influence the quality of the internal spaces and the external environments of cities.

A healthy and safe built environment should be developed with the principles of sustainable development at its heart. Sustainable development is often classified according to the definition by the World Commission on Environment and Development (WCED), where development meets "the needs of the present without compromising the ability of future generations to meet their own needs" [7]. The WCED defines the concept of sustainable development as a strategy towards sustainability by optimizing the link between global society and its natural environment, taking into account society's social, economic and environmental goals. In their investigations of the built environment, foreign scientists also consider the three basic principles of sustainable development [8-12]. Huang and Yin [8], for instance, carried out an empirical study using hedonic price models to examine a comprehensive set of environmental sustainability elements including green spaces, transit systems and central business districts (CBDs), which showed that environmental sustainability elements had the greatest impact on house prices. Barbosa and Almeida [9] proposed the Sustainability Panel tool, which was designed to reveal separately the status of the dimensions in sustainable development (environmental, social and economic).

Various MCDM methods, such as Analytical Hierarchy Process (AHP), Elimination and Choice Expressing the Reality (in french "ELimination Et Choix Traduisant la REalité") (ELECTRE), Technique for Order of Preference by Similarity to Ideal Solution (TOPSIS), COmplex PRoportional ASsessment (COPRAS) and Analysis Network Process (ANP) [13-19], can be applied to analyze a sustainable built environment. Karaca et al. [13] applied the fuzzy AHP and ELECTRE methods for a sustainability analysis of a futuristic idea, "City-Blood". Mulliner et al. [14] integrated AHP, TOPSIS and COPRAS for sustainable housing affordability. Nilashi et al. [15] developed a knowledge-based expert system for assessing the performance level of green buildings by using the AHP method. In the analysis of a healthy and safe built environment, this article also applies the MCDM methods: COPRAS, Simple Additive Weighting (SAW), TOPSIS, Evaluation based on Distance from Average Solution (EDAS) [20-22].

Environmental sustainability must go hand-in-hand with other important goals, such as promoting economic development, decreasing poverty and improving quality of life. The green agenda is a necessary part of holistic, city-led strategies for economic, social and environmental sustainability [23].

\section{Research Methodology}

The aim of this article is to assess a healthy and safe built environment. To reach this aim, secondary objectives are: (1) to integrate the principles of sustainable development; (2) to integrate MCDM methods; (3) to assess 21 neighborhoods in Vilnius. Figure 1 presents the research methodology.

Sustainable urban development is an attempt to ensure the balanced development of cities and their subdivisions to safeguard their citizens' welfare now without compromising their quality of life in the future. Social, economic, environmental and other sciences offer various methods for that purpose. Sustainable urban development aims to reduce poverty, improve the quality of life and social connections and relationships in communities, meet fundamental human needs, promote sustainable economic and political development and prevent harm to natural resources [24,25]. 


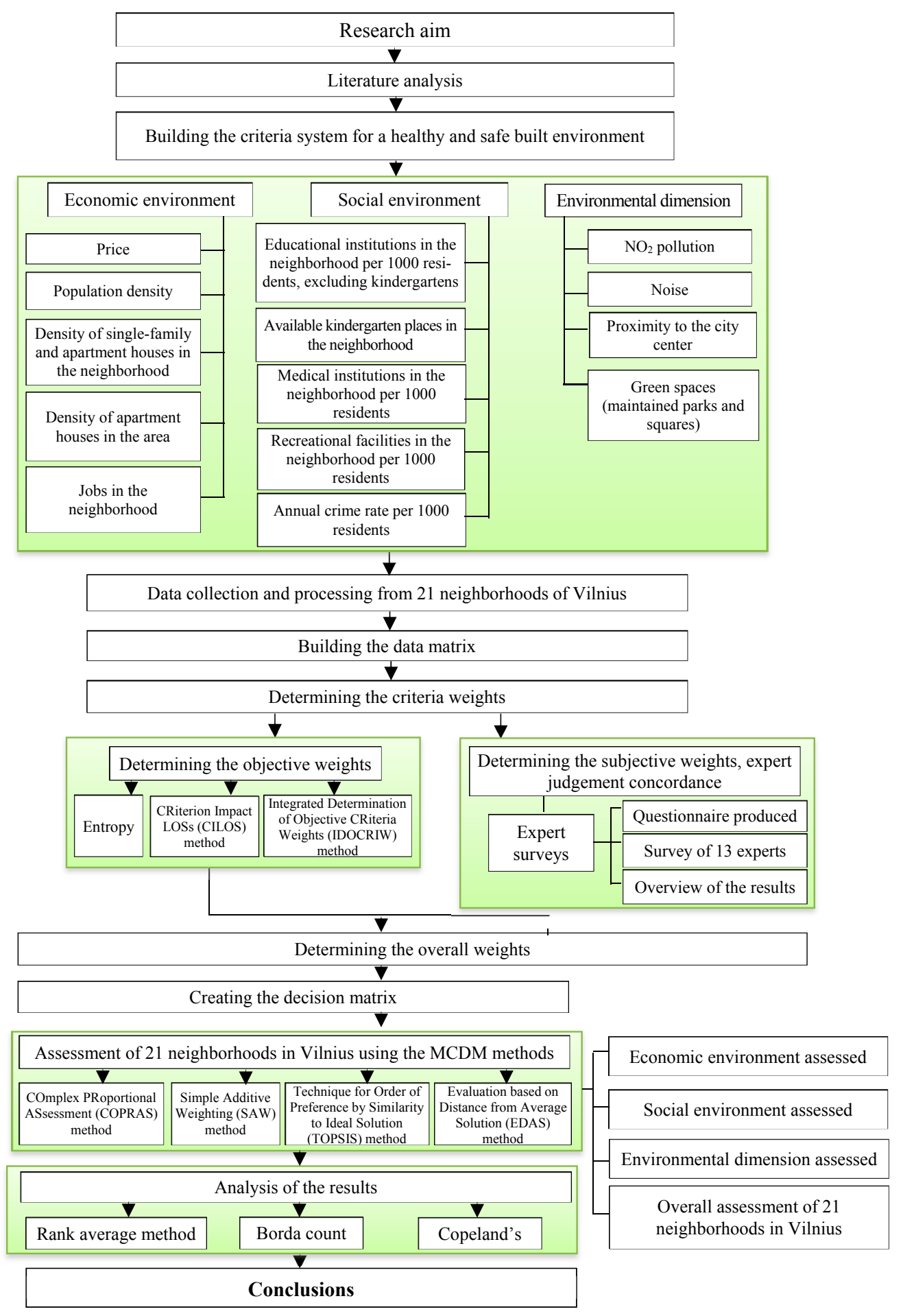

Figure 1. Research methodology.

Sustainable urban development can be seen as a yin-yang balance with contradicting goals [26-28]. Economic growth, for instance, is impossible without increasing the use of resources $[29,30]$. Therefore, some scientists propose lower consumption as a way of saving the environment. Sustainable economic development may not include the ecological, social and cultural dimensions of sustainable development. Debates are common in the scientific literature about whether a balance between the economic, environmental and social development of the built environment and cultural diversity is 
attainable in practice. Multiple criteria analysis methods are, therefore, perfect for the analysis of the sustainable development of cities and their subdivisions [31-34].

Many multiple criteria analysis methods are available [35-38]. The results they produce for the same problem with identical criteria, values and weights are often different. Therefore, the question is: which of these methods is the best option for specific problems [39-43]. Attempts to determine the superior multiple criteria analysis method have always been a source of many arguments and endless debates. Competing methods always exist. Often it is very difficult to establish whether the answer to a specific multiple criteria analysis method produced is right or wrong. To escape these issues, authors propose solving the same problem with an integrated set of multiple criteria analysis methods [44-46].

The integrated methodology of the multiple criteria analysis methods is presented below as a case analysis of 21 neighborhoods in Vilnius.

The literature analysis presented in Section 2 was the first step in the assessment of the healthy and safe built environment in the neighborhoods in Vilnius. Three key areas were identified in the criteria: the economic environment, the social environment and the environmental dimension. Based on the literature analysis, a criteria system for the assessment of a healthy and safe built environment was created. The data that were collected and processed are presented in a data matrix (Section 3). Data alone are not enough, however, for the assessment of the 21 neighborhoods in Vilnius. The objective criteria weights were determined using the entropy, CRiterion Impact LOSs (CILOS) and Integrated Determination of Objective CRiteria Weights (IDOCRIW) methods. The subjective weights were determined by expert judgement with 13 property experts surveyed using a questionnaire. Nine experts work for property companies, two for associations dealing with property, one for a construction company and one for an educational institution offering a property management study program. Of those involved in the assessment, $77 \%$ were female and $23 \%$ were male. All of the experts have university degrees. A look at the experience of the experts shows that $53.8 \%$ have been in property for $5-10$ years, $38.5 \%$ have been in the field for less than five years and $7.7 \%$ have $10-15$ years in the field. Section 4 outlines the theory of the computations behind the objective, subjective and overall weights. The COPRAS, SAW, TOPSIS and EDAS MCDM methods were applied in the assessment of the healthy and safe built environment in the neighborhoods in Vilnius. Section 5 deals with the theory of their computations. Section 6 presents the results, i.e., the computations of the objective, subjective and overall weights, the use of the MCDM methods in the neighborhood assessment according to each area (the economic environment, the social environment and the environmental dimension) alone and in the overall context. The overall results for the 21 neighborhoods in Vilnius were processed using the rank average, Borda count and Copeland's methods (Section 7). The discussion and conclusions follow in Section 8.

\section{Criteria of a Sustainable Built Environment and the Assessment Criteria for a Healthy and Safe Built Environment}

A built environment is developed in order to satisfy the residents' requirements. Human needs can be physiological or social and are related to security, respect and self-expression. People are interested in ecologically clean and almost noiseless environments with sufficient options for relaxation, shopping, easy access to work or other destinations and good relationships with neighbors [47].

Both indoor and outdoor built spaces affect human health. Buildings play a role in a person's quality of life, work and recreation, as well as health. Keall et al. [48], for instance, tested the safety benefits of home modifications. The results suggest that about $38 \%$ of the home injuries studied were potentially related to a structural aspect of the home environment [49]. Buildings are also a significant source of pollution. They account for almost half of sulfur dioxide emissions, $25 \%$ of nitrous oxide emissions, $10 \%$ of particulate matter emissions and about $35 \%$ of carbon emissions, all contributing to climate change [47].

According to the classical conception, sustainable development consists of social, economic and environmental components [50]. Urbanization and growing numbers of construction projects lead 
to greater building and population densities. Anderson et al.'s [1] detailed analysis shows that the influence of density on carbon dioxide is limited and can vary significantly between households in similar density locations due to socio-economic factors. High residential density is an important element of the compact city concept alongside mixed land use, well-connected urban layouts and easily accessible public transport networks [51]. Dempsey et al. [51] specifically makes reference to the relationship between density and aspects of social sustainability, specifically social equity, environmental equity and sustainability of community.

A sustainable built environment is, therefore, inseparable from attempts to build sustainable communities [14,51-58]. Maliene and Malys [52] developed a model of sustainable housing development for sustainable communities, which can be adapted to any town and which will help to create healthy and attractive communities. Sustainable housing is characterized as being available, good quality, economical, ecological, comfortable and cozy. For communities to be sustainable, they must provide hospitals, schools, shops, good public transport, open public spaces and a clean and safe environment. According to Maliene and Malys [52], most importantly, sustainable communities must provide decent homes at prices people can afford. According to Ceccato and Lukyte [53], a sustainable community is a place free from the fear of crime, where a feeling of security underpins a wider sense of place attachment and place attractiveness. Researchers propose that safety is a central dimension of the contemporary debate on urban sustainable development. Viteikiene and [50], Dempsey et al. [51], Lee et al. [54], Charoenkit, Kumar [59], Conejos et al. [60,61], Cozens [62] and others have also analyzed the criteria of safety. Cozens [62] claims that such issues as crime and the fear of crime are not effectively represented within most sustainability agendas and require explicit inclusion. He provides recommendations for integrating crime and the fear of crime within urban sustainability [62].

In terms of a healthy and safe environment, outdoor recreation is an inseparable assessment criteria for a sustainable built environment. Engaging in outdoor recreation contributes significantly to the better physical, mental and spiritual health of individuals [63]. Green spaces, including open water and parks, are a significant component in health promotion and play an important role in improving the health of cities and their residents [8].

A summary of previous research is shown in Table 1. A bibliometric analysis of the criteria subsystems and the criteria defining the assessment system of a healthy and safe built environment is presented in Table 2.

Table 1. Summary of previous research.

\begin{tabular}{|c|c|}
\hline Authors & $\begin{array}{l}\text { Assessment Criteria for a Sustainable Built Environment as a Building Block of a Healthy } \\
\text { and Safe Environment }\end{array}$ \\
\hline Anderson et al. [1] & $\begin{array}{l}\text { Urban form, density (residential, job, neighborhoods), transportation, } \\
\text { infrastructure, consumption. }\end{array}$ \\
\hline Huang and Yin [8] & House prices, green spaces. \\
\hline Mulliner et al. $[14,57]$ & $\begin{array}{l}\text { House prices in relation to incomes, rental costs in relation to incomes, interest rates and } \\
\text { mortgage availability, availability of social and private rented accommodation, availability of } \\
\text { affordable home ownership products, safety (crime level), access to employment opportunities, } \\
\text { access to public transport services, access to good quality schools, access to shops, access to } \\
\text { health services, access to childcare, access to leisure facilities, access to open green public spaces, } \\
\text { quality of housing, energy efficiency of housing, availability of waste management facilities, } \\
\text { desirability of the neighborhood area, deprivation in the area, environmental problems } \\
\text { (e.g., litter, traffic). }\end{array}$ \\
\hline Kaklauskas et al. [47] & $\begin{array}{l}\text { Green spaces, infrastructure, transportation, unemployment, vandalism, education, } \\
\text { neighborhood, air quality, social and recreational centers, ecologically-clean and almost } \\
\text { noiseless environments. }\end{array}$ \\
\hline $\begin{array}{l}\text { Viteikiene and } \\
\text { Zavadskas [50] }\end{array}$ & $\begin{array}{l}\text { The city center is close, extensive supply of trade services, the schools are close, the } \\
\text { kindergartens are close, extensive recreational opportunities, clean air, a nice environment, safe, } \\
\text { good transport service to the city center, good transport service to the workplace, a } \\
\text { well-attended environment, no noise, no drug addicts, the policlinics are close, the drugstores } \\
\text { are close, good facilities for sports, lots of cultural institutions, no alcoholics in sight, no } \\
\text { homeless people in sight, the workplace is close, pleasant architecture, well-attended parks. }\end{array}$ \\
\hline
\end{tabular}


Table 1. Cont.

\begin{tabular}{|c|c|}
\hline Authors & $\begin{array}{l}\text { Assessment Criteria for a Sustainable Built Environment as a Building Block of a Healthy } \\
\text { and Safe Environment }\end{array}$ \\
\hline Dempsey et al. [51] & $\begin{array}{l}\text { Density, accessible public transport networks, access to services and facilities, safety, job } \\
\text { opportunities, education, the neighborhood, green/open spaces, safety and security. }\end{array}$ \\
\hline Maliene and Malys [52] & $\begin{array}{l}\text { Hospitals, schools, shops, good public transport, clean and safe environment, open public } \\
\text { spaces, affordability, technical and hygienic requirements, energy saving, ecological } \\
\text { building materials. }\end{array}$ \\
\hline Ceccato and Lukyte [53] & Crime level. \\
\hline Lee et al. [54] & $\begin{array}{l}\text { Housing, neighborhood facilities, childcare facilities, infrastructure, recreation and open space, } \\
\text { health and safety, community safety, sport, leisure and recreation. }\end{array}$ \\
\hline Sohn [58] & $\begin{array}{l}\text { Density (residential crime, population, bus-stops, parks, streets, intersections), distance to the } \\
\text { closest police station, median household income score, average number of building stories. }\end{array}$ \\
\hline Charoenkit and Kumar [59] & $\begin{array}{l}\text { Efficient use of land, walkability, access to public transport, safety, number of } \\
\text { jobs/schools/amenities/parks, hospitals, etc., number of residential units, density. }\end{array}$ \\
\hline Conejos et al. $[60,61]$ & Density, accessibility, occupational health, safety and security, neighborhood and amenity. \\
\hline Cozens [62] & Crime level. \\
\hline Arni and Khairil [63] & Green spaces, recreation and leisure. \\
\hline Chan and Lee [64] & $\begin{array}{l}\text { Mass transport, houses, schools, care centers, hospitals, schools, leisure activities, availability of } \\
\text { job opportunities, safety and security, density, open spaces and green areas, without traveling } \\
\text { too far. }\end{array}$ \\
\hline Deng and Quigley [65] & Average transaction price, housing stock. \\
\hline El Asmar and Taki [66] & Air pollution, water pollution, building density, population, noise. \\
\hline Fitzgerald et al. [67] & $\begin{array}{l}\text { The criteria are grouped into the environment index (recycling, per capita waste volume, } \\
\text { sewerage connections, forest areas within a } 10-\mathrm{km} \text { radius, green energy interests, transport } \mathrm{CO}_{2} \\
\text { emissions, level of wastewater treatment etc.), the Socio-Economic index (services index, } \\
\text { population density, households with central heating, house price income ratio etc.), the Quality } \\
\text { of Life index (health insurance cover, distance to the nearest hospital, community involvement, } \\
\text { odor problems, noise problems, sports area satisfaction, green area satisfaction etc.), the } \\
\text { Transport index (relative car use, work distance }<8 \mathrm{~km} \text {, work distance }>24 \mathrm{~km} \text {, public transport } \\
\text { use, km to the nearest train station, traffic flow index, monthly distance travelled to shops, } \\
\text { distance to work, etc.). }\end{array}$ \\
\hline $\begin{array}{l}\text { Lamķquiz and } \\
\text { López-Domksnguez [68] }\end{array}$ & Mobility habits, population, job, neighborhood, accessibility. \\
\hline Nuuter et al. [69] & $\begin{array}{l}\text { General economic criteria (GDP per capital, unemployment rate, inflation rate), housing stock } \\
\text { criteria (total dwelling stock, number of dwellings, private ownership rate etc.), housing } \\
\text { affordability criteria (total housing costs in Purchasing Power Standards (PPS), share of housing } \\
\text { costs in disposable incomes, harmonized consumer price in housing index, aggregated } \\
\text { affordability index, normal house price index etc.), population and social conditions (inequality } \\
\text { of income distribution, population at risk of poverty, population with severe housing } \\
\text { deprivation, etc.), housing quality criteria (housing overcrowding rate, average household size, } \\
\text { etc.), environmental quality criteria (healthcare index, traffic index, noise from neighbors and } \\
\text { street, pollution, crime, quality of life index, etc.). }\end{array}$ \\
\hline Oltean-Dumbrava et al. [70] & Noise level, pollution. \\
\hline Sun et al. [71] & $\begin{array}{l}\text { The criteria for economic development mainly reflect three aspects of the urban economy: } \\
\text { overall economic strength, people's living standards and the industrial structure. The criteria for } \\
\text { social progress mainly reflect three aspects of urban society: population quality, public services } \\
\text { and living conditions. The criteria for the ecological infrastructure construction mainly include } \\
\text { three perspectives of urban ecological infrastructure: the number of green spaces, land } \\
\text { utilization and pollution control. }\end{array}$ \\
\hline Xing et al. [72] & $\begin{array}{l}\text { Environmental impact: energy, depletion of resource, climate changes: } \mathrm{CO}_{2} \text { emissions, land use, } \\
\text { waste, air pollution, biodiversity, water pollution, noise, ground pollution. } \\
\text { Social impact: health, quality of life, crime, transportation, leisure, social capital, security, high } \\
\text { unemployment, social equity, cultural diversity. } \\
\text { Economic impact: whole life cost, job creation, economic growth, unaffordable housing, } \\
\text { socio-economic inequity, economic development, wealth, distribution of wealth, leakage from } \\
\text { local economies, built facilities/service. }\end{array}$ \\
\hline Yin et al. [73] & $\begin{array}{l}\text { Population density, housing affordability, greenhouse gas emissions, protection of open spaces, } \\
\text { environmentally sensitive habitats, road accessibility. }\end{array}$ \\
\hline
\end{tabular}


Table 2. Bibliometric analysis of the criteria subsystems and the criteria defining the Assessment System of a Healthy and Safe Built Environment.

\begin{tabular}{|c|c|c|}
\hline & Science Direct, Publications & Google Scholar, Results \\
\hline "Healthy and safe" "built environment" "cost" & 13,110 & 16,000 \\
\hline \multicolumn{3}{|l|}{$\begin{array}{l}2017(45), 2016(1065), 2015(987), 2014(901), 2013(781), 2012 \\
(730), 2011(513), 2010(536), 2009(487), 2008(549), 2007(488) \text {, } \\
2006(472), 2005(461), 2004(341), 2003(350), 2002(312), 2001 \\
(310), 2000(264), 1999(238), 1998(222), 1997 \text { and earlier }(3058)\end{array}$} \\
\hline \multicolumn{3}{|l|}{$\begin{array}{l}2017(20), 2016(418), 2015(355), 2014(314), 2013(291), 2012 \\
(291), 2011(178), 2010(183), 2009(146), 2008(162), 2007(141), \\
2006(127), 2005(172), 2004(100), 2003(124), 2002(99), 2001 \\
(98), 2000(79), 1999(70), 1998(59), 1997 \text { and earlier }(1119)\end{array}$} \\
\hline \multicolumn{3}{|l|}{ Subsystem of social environment criteria } \\
\hline "Healthy and safe" “built environment" "schools" & 7239 & 8660 \\
\hline \multicolumn{3}{|l|}{$\begin{array}{l}2017(21), 2016(633), 2015(574), 2014(547), 2013(494), 2012 \\
(413), 2011(307), 2010(325), 2009(303), 2008(353), 2007(272), \\
2006(288), 2005(247), 2004(156), 2003(161), 2002(138), 2001 \\
(136), 2000(133), 1999(98), 1998(85), 1997 \text { and earlier }(1555)\end{array}$} \\
\hline "Healthy and safe" "built environment" "pre-school" & 324 & 409 \\
\hline \multicolumn{3}{|l|}{$\begin{array}{l}2016(11), 2015(12), 2014(15), 2013(20), 2012(6), 2011(9), 2010 \\
(11), 2009(8), 2008(16), 2007(10), 2006(4), 2005(6), 2004 \text { (3), } \\
2003(3), 2002(2), 2001(4), 2000(3), 1999(7), 1998(7), 1997(3), \\
1996 \text { and earlier (24) }\end{array}$} \\
\hline "Healthy and safe" "built environment" "leisure" & 1282 & 4340 \\
\hline \multicolumn{3}{|l|}{ 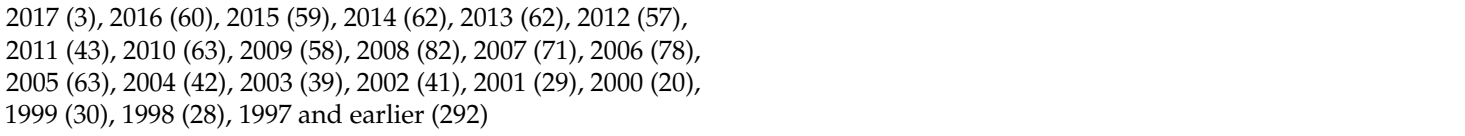 } \\
\hline "Healthy and safe" "built environment" "crime" & 1310 & 4290 \\
\hline \multicolumn{3}{|l|}{$\begin{array}{l}2017 \text { (4), } 2016 \text { (109), } 2015 \text { (92), } 2014(85), 2013(109), 2012 \text { (63), } \\
2011 \text { (54), } 2010 \text { (58), } 2009 \text { (50), } 2008 \text { (71), } 2007 \text { (53), } 2006 \text { (66), } \\
2005 \text { (56), } 2004 \text { (26), } 2003 \text { (34), } 2002 \text { (28), } 2001(32), 2000(28) \text {, } \\
1999 \text { (15), } 1998 \text { (17), } 1997 \text { and earlier (260) }\end{array}$} \\
\hline \multicolumn{3}{|l|}{ Subsystem of environmental criteria } \\
\hline "Healthy and safe" "built environment" "pollution" & 5574 & 8490 \\
\hline \multicolumn{3}{|l|}{$\begin{array}{l}2017(11), 2016(447), 2015(355), 2014(353), 2013(290), 2012 \\
(301), 2011(213), 2010(179), 2009(191), 2008(204), 2007(155) \text {, } \\
2006(166), 2005(202), 2004(127), 2003(131), 2002(143), 2001 \\
(138), 2000(121), 1999(102), 1998(106), 1997 \text { and earlier (1639) }\end{array}$} \\
\hline "Healthy and safe" "built environment" "noise" & 3594 & 6170 \\
\hline
\end{tabular}


Table 2. Cont.

\begin{tabular}{|c|c|c|}
\hline & Science Direct, Publications & Google Scholar, Results \\
\hline "Healthy and safe" "built environment" "distance" & 5639 & 7490 \\
\hline $\begin{array}{l}2017 \text { (24), } 2016 \text { (472), } 2015 \text { (438), } 2014 \text { (369), } 2013 \text { (360), } 2012 \\
(341), 2011 \text { (229), } 2010 \text { (255), } 2009 \text { (198), } 2008 \text { (236), } 2007(208) \text {, } \\
\text { 2006 (178), } 2005 \text { (190), 2004 (136), 2003 (166), } 2002(126), 2001 \\
(114), 2000 \text { (110), } 1999 \text { (86), 1998 (90), } 1997 \text { and earlier (1313) }\end{array}$ & & \\
\hline "Healthy and safe" "built environment" "parks" & 4002 & 5510 \\
\hline $\begin{array}{l}2017 \text { (9), } 2016 \text { (290), } 2015 \text { (240), } 2014 \text { (246), } 2013(232), 2012 \\
(202), 2011 \text { (151), } 2010 \text { (166), } 2009 \text { (167), } 2008 \text { (194), } 2007 \text { (157), } \\
2006 \text { (158), } 2005 \text { (157), } 2004(89), 2003 \text { (88), } 2002 \text { (98), } 2001 \text { (83), } \\
2000 \text { (77), } 1999 \text { (64), } 1998 \text { (56), } 1997 \text { and earlier (1078) }\end{array}$ & & \\
\hline
\end{tabular}

This article aims to assess the built environment in view of the principles of sustainable development with a focus on a healthy and safe environment. Analysis shows that, although researchers integrate different assessment criteria, the criteria are sorted under three labels of key sustainable development principles: economic, social and environmental. An analysis of the worldwide literature suggests that authors use different criteria systems in their assessments of a healthy and safe environment (Table 1). Table 3 summarizes the results. It lists the overall prevailing criteria and presents the system of criteria against which a healthy and safe environment is assessed. The number of sustainable built environment criteria analyzed during the project "Construction and Real Estate-Developing Indicators for Transparency" was in the hundreds [74]. In view of the results summarized in Tables 1-3, the authors have drawn up an assessment system for a sustainable built environment with a focus on the principles of health and safety from a holistic perspective. The assessment criteria for a healthy and safe built environment based on the principles of sustainability are as follows:

- Economic environment factors:

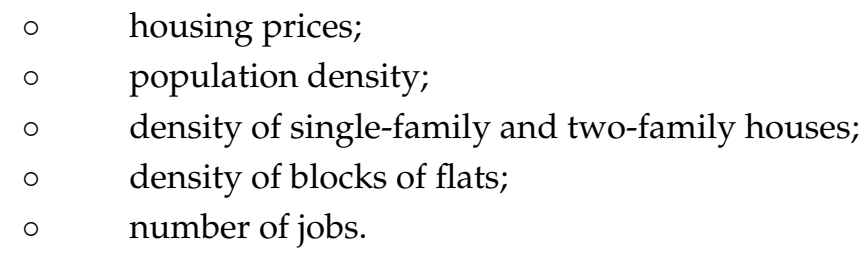

- Social environment factors:

- number of educational institutions (except for kindergartens);

- number of places in kindergartens;

- number of healthcare institutions;

- number of recreational facilities;

- crime rates.

- Environmental factors:

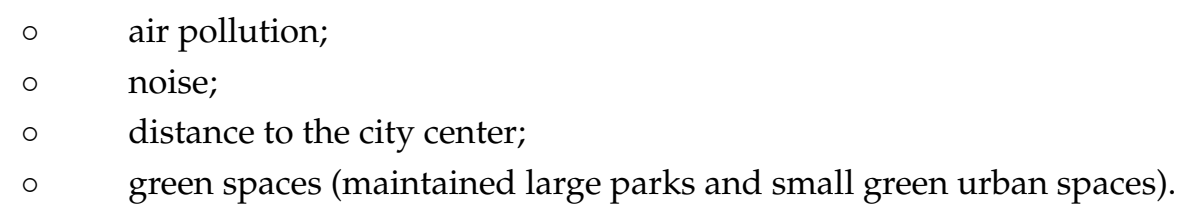


Table 3. Drawing up the system of the assessment criteria for a healthy and safe built environment based on the principles of sustainability.

\begin{tabular}{|c|c|c|c|c|c|c|c|c|c|c|c|c|c|c|c|}
\hline & \multicolumn{5}{|c|}{ Economic Environment Factors } & \multicolumn{5}{|c|}{ Social Environment Factors } & \multicolumn{4}{|c|}{ Environmental Factors } & \multirow[b]{2}{*}{$\%^{1}$} \\
\hline & $\begin{array}{l}\text { Housing } \\
\text { Prices }\end{array}$ & $\begin{array}{l}\text { Population } \\
\text { Density }\end{array}$ & $\begin{array}{c}\text { Density of } \\
\begin{array}{c}\text { Single-Family } \\
\text { and }\end{array} \\
\text { Two-Family } \\
\text { Houses }\end{array}$ & $\begin{array}{c}\text { Density } \\
\text { of } \\
\text { Blocks } \\
\text { of Flats }\end{array}$ & $\begin{array}{l}\text { Number } \\
\text { of Jobs }\end{array}$ & $\begin{array}{c}\text { Number of } \\
\text { Educational } \\
\text { Institutions } \\
\text { (Except for } \\
\text { Kindergartens) }\end{array}$ & $\begin{array}{l}\text { Number of } \\
\text { Places in } \\
\text { Kindergartens }\end{array}$ & $\begin{array}{l}\text { Number of } \\
\text { Healthcare } \\
\text { Institutions }\end{array}$ & $\begin{array}{l}\text { Number of } \\
\text { Recreational } \\
\text { Facilities }\end{array}$ & $\begin{array}{l}\text { Crime } \\
\text { Rates }\end{array}$ & $\begin{array}{c}\text { Air } \\
\text { Pollution } \\
\mathrm{NO}_{2}\end{array}$ & Noise & $\begin{array}{l}\text { Distance } \\
\text { to the } \\
\text { City } \\
\text { Centre }\end{array}$ & $\begin{array}{l}\text { Green Spaces } \\
\text { (Maintained } \\
\text { Large Parks and } \\
\text { Small Green } \\
\text { Urban Spaces) }\end{array}$ & \\
\hline Anderson et al. [1] & & + & + & + & + & & & & & & & & + & & 35.71 \\
\hline Huang and Yin $[8]$ & + & & & & + & & & & & & & & + & + & 28.57 \\
\hline Mulliner et al. $[14,57]$ & + & & & & + & + & + & + & + & + & & & + & + & 64.29 \\
\hline Kaklauskas et al. [47] & & & & & + & + & & + & + & + & + & + & + & + & 64.29 \\
\hline Viteikiene and Zavadskas [50] & & + & & & + & + & + & + & + & + & + & + & + & + & 78.57 \\
\hline Dempsey et al. [51] & & + & + & + & + & & & & & + & + & & + & + & 57.14 \\
\hline Maliene and Malys [52] & + & & & & & + & + & + & + & + & + & & & + & 57.14 \\
\hline Ceccato and Lukyte [53] & & + & & & + & & & & & + & & & & & 21.43 \\
\hline Lee et al. [54] & & + & & & & & + & + & + & + & & & & + & 42.86 \\
\hline Sohn [58] & & + & & & & & & & & + & & & + & + & 28.57 \\
\hline Charoenkit and Kumar [59] & & & + & + & + & + & + & + & + & + & & & + & + & 71.43 \\
\hline Conejos et al. [60,61] & & + & & & & & & + & & + & & & + & & 28.57 \\
\hline Cozens [62] & & + & & & & & & & & + & & & & & 14.29 \\
\hline Arni and Khairil [63] & & & & & & & & & + & & & & & + & 14.29 \\
\hline Chan and Lee [64] & & + & + & + & + & + & + & + & + & + & & & + & + & 78.57 \\
\hline Deng and Quigley [65] & + & & + & + & & & & & & & & & & & 21.43 \\
\hline El Asmar and Taki [66] & & + & + & + & & & & & & & + & + & & & 35.71 \\
\hline Fitzgerald et al. [67] & + & + & & & + & + & & + & + & & + & + & + & + & 71.43 \\
\hline $\begin{array}{c}\text { Lamķquiz and } \\
\text { López-Domḳnguez [68] }\end{array}$ & & + & & & + & & & & & & & & + & & 21.43 \\
\hline Nuuter et al. [69] & + & + & + & + & & & & + & & + & + & + & & & 57.14 \\
\hline Oltean-Dumbrava et al. [70] & & & & & & & & & & & + & + & & & 14.29 \\
\hline Sun et al. [71] & + & + & & & & & & + & & & + & & & + & 35.71 \\
\hline Xing et al. [72] & + & & & & + & + & + & + & + & + & + & + & & & 64.29 \\
\hline Yin et al. [73] & + & + & & & & & & & & & & & + & + & 28.57 \\
\hline$\%^{2}$ & 38.46 & 61.54 & 26.92 & 26.92 & 50.00 & 34.62 & 30.77 & 53.85 & 42.31 & 61.54 & 38.46 & 26.92 & 57.69 & 57.69 & \\
\hline
\end{tabular}

${ }^{1}$ Calculations were made to determine the percentage proportion of the criteria proposed by the authors of this article made in articles by other authors. ${ }^{2}$ Calculations were made to determine the percentage proportion of the criteria proposed by the authors of this article made in the literature review. 


\section{Selection of the Survey Object}

Vilnius is the capital of Lithuania. It is leader over the other cities in the country with the biggest population concentration and the largest economic potential. Its future is connected to ongoing urbanization processes, open market changes and evolution (Vilniaus miesto savivaldybe 2007). For this reason, Vilnius is the focus of this research.

Vilnius comprises 21 neighborhoods: Verkiai, Antakalnis, Pašilaičiai, Fabijoniškès, Pilaitè, Justiniškès, Viršuliškès, Šeškinè, Šnipiškès, Žirmūnai, Karoliniškès, Žvèrynas, Grigiškès, Lazdynai, Vilkpèdè, Naujamiestis, Senamiestis, Naujoji Vilnia, Paneriai, Naujininkai and Rasos. A healthy and safe built environment was assessed within the boundaries of these neighborhoods. The data were collected and processed from various sources, such as Statistics Lithuania, the Vilnius City Municipality, the Vilnius City Social Support Centre, the property portal Aruodas. It, the online portal Kurgyvenu. It run by CodeIn, the National Public Health Surveillance Laboratory and Google Maps. Table 4 presents the input data matrix for the alternatives that are assessed. 
Table 4. The input data matrix for the assessment of the neighborhoods in Vilnius.

\begin{tabular}{|c|c|c|c|c|c|c|c|c|c|c|c|c|c|}
\hline & & $\begin{array}{l}\text { Matavimo } \\
\text { Vnt }\end{array}$ & $\begin{array}{l}\text { Min/ } \\
\text { Max* }\end{array}$ & Antakalnis & Fabijoniškès & Grigiškès & Justiniškès & Karoliniškės & Lazdynai & Naujamiestis & Naujininkai & $\begin{array}{l}\text { Naujoji } \\
\text { Vilnia }\end{array}$ & Paneriai \\
\hline \multirow{5}{*}{$\begin{array}{l}\text { Economic } \\
\text { environment } \\
\text { factors }\end{array}$} & Housing prices & Eur $/ \mathrm{m}^{2}$ & - & 1888.34 & 1154.10 & 676.10 & 1080.61 & 1222.06 & 1190.30 & 1711.44 & 967.13 & 854.64 & 950.14 \\
\hline & Population density & $\begin{array}{c}\text { Residents } \\
\text { number } / \mathrm{km}^{2}\end{array}$ & - & 504.40 & 9697.32 & 1580.99 & 9215.44 & 6817.50 & 3019.13 & 4840.00 & 758.42 & 793.16 & 91.12 \\
\hline & $\begin{array}{l}\text { Density of single-family } \\
\text { and two-family houses }\end{array}$ & Number $/ \mathrm{km}^{2}$ & + & 44.62 & 106.59 & 76.90 & 39.26 & 11.50 & 54.66 & 116.04 & 40.54 & 89.03 & 19.11 \\
\hline & Density of blocks of flats & $\begin{array}{l}\text { Number } \\
/ \mathrm{km}^{2}\end{array}$ & - & 3.60 & 42.20 & 14.79 & 86.58 & 12.75 & 14.17 & 33.54 & 6.18 & 8.22 & 1.04 \\
\hline & $\begin{array}{l}\text { Number of jobs per } \\
1000 \text { residents }\end{array}$ & Number & + & 18.20 & 9.30 & 2.00 & 4.60 & 7.20 & 7.20 & 94.60 & 21.50 & 11.00 & 41.70 \\
\hline \multirow{5}{*}{$\begin{array}{l}\text { Social } \\
\text { environment } \\
\text { factors }\end{array}$} & $\begin{array}{l}\text { Number of educational } \\
\text { institutions (except for } \\
\text { kindergartens) }\end{array}$ & $\begin{array}{l}\text { Institutions } \\
1000 \text { residents }\end{array}$ & + & 0.4366 & 0.2515 & 0.3563 & 0.2549 & 0.3667 & 0.2894 & 0.5596 & 0.1925 & 0.5454 & 0.3876 \\
\hline & $\begin{array}{c}\text { Number of places in } \\
\text { kindergartens }\end{array}$ & Number & + & 1630 & 1567 & 634 & 1731 & 1541 & 2104 & 1507 & 1371 & 1250 & 318 \\
\hline & $\begin{array}{l}\text { Number of healthcare } \\
\text { institutions per } \\
1000 \text { residents }\end{array}$ & $\begin{array}{l}\text { Institutions } \\
1000 \text { residents }\end{array}$ & + & 0.4622 & 0.1006 & 0.0891 & 0.1821 & 0.1100 & 0.0965 & 0.3444 & 0.1283 & 0.0962 & 0.2584 \\
\hline & $\begin{array}{l}\text { Recreational facilities in } \\
\text { the neighborhood per } \\
1000 \text { residents }\end{array}$ & $\begin{array}{l}\text { Institutions } \\
1000 \text { residents }\end{array}$ & + & 0.0770 & 0.1006 & 0.5345 & 0.1457 & 0.1834 & 0.0965 & 0.3874 & 0.2566 & 0.1283 & 0.3876 \\
\hline & $\begin{array}{l}\text { Annual crime rate per } \\
1000 \text { residents }\end{array}$ & Number & - & 5.6497 & 6.2627 & 5.7907 & 4.843 & 5.6105 & 4.7395 & 13.1284 & 15.2385 & 8.9562 & 13.6951 \\
\hline \multirow{4}{*}{$\begin{array}{l}\text { Environmental } \\
\text { factors }\end{array}$} & Air pollution $\mathrm{NO}_{2}$ & $\mu \mathrm{g} / \mathrm{m}^{3}$ & - & 16.5 & 18.4 & 12.8 & 8.9 & 19.89 & 33.4 & 16.87 & 11.6 & 19.92 & 15.15 \\
\hline & Noise & $\mathrm{dB}$ & - & 69.4 & 62.93 & 64.49 & 44.2 & 55.57 & 56.22 & 56.94 & 54.37 & 52.05 & 53.29 \\
\hline & Distance to the city center & $\mathrm{km}$ & - & 4.3 & 5.4 & 19.8 & 6.6 & 6.9 & 7.1 & 1.6 & 4.1 & 12.6 & 14.3 \\
\hline & $\begin{array}{l}\text { Green spaces (maintained } \\
\text { large parks and small } \\
\text { green urban spaces) }\end{array}$ & $\%$ & + & 7.20 & 11.15 & 1.14 & 1.34 & 7.39 & 2.69 & 1.83 & 1.22 & 3.43 & 1.22 \\
\hline
\end{tabular}


Table 4. Cont.

\begin{tabular}{|c|c|c|c|c|c|c|c|c|c|c|c|c|c|c|}
\hline & & $\begin{array}{l}\text { Matavimo } \\
\text { Vnt }\end{array}$ & $\begin{array}{l}\operatorname{Min} / \\
\operatorname{Max} *\end{array}$ & Pašilaičiai & Pilaitè & Rasos & Senamiestis & Šeškinè & Verkiai & Vilk-pèdè & Viršu-liškès & Žirmūnai & Žvèrynas & Šnipiškès \\
\hline \multirow{5}{*}{$\begin{array}{l}\text { Economic } \\
\text { environment } \\
\text { factors }\end{array}$} & Housing prices & Eur $/ \mathrm{m}^{2}$ & - & 1136.80 & 1243.52 & 1601.00 & 2221.89 & 1055.02 & 1481.19 & 1205.37 & 1175.03 & 1582.93 & 2153.47 & 1612.65 \\
\hline & Population density & $\begin{array}{l}\text { Residents } \\
\text { number } / \mathrm{km}^{2}\end{array}$ & - & 4031.22 & 1472.46 & 834.41 & 4321.56 & 7121.14 & 757.93 & 2072.43 & 5893.20 & 5455.29 & 4103.33 & 4917.31 \\
\hline & $\begin{array}{l}\text { Density of single-family } \\
\text { and two-family houses }\end{array}$ & Number $/ \mathrm{km}^{2}$ & + & 74.88 & 48.84 & 97.48 & 186.22 & 55.00 & 70.87 & 38.54 & 22.80 & 23.18 & 256.30 & 188.78 \\
\hline & Density of blocks of flats & $\begin{array}{l}\text { Number } \\
/ \mathrm{km}^{2}\end{array}$ & - & 13.29 & 7.68 & 9.37 & 40.67 & 41.36 & 5.03 & 11.55 & 31.60 & 27.65 & 72.59 & 56.09 \\
\hline & $\begin{array}{l}\text { Number of jobs (per } \\
1000 \text { residents) }\end{array}$ & Number & + & 10.70 & 6.00 & 7.70 & 49.20 & 9.20 & 22.30 & 9.50 & 7.30 & 37.90 & 10.40 & 21.50 \\
\hline \multirow{5}{*}{$\begin{array}{l}\text { Social } \\
\text { environment } \\
\text { factors }\end{array}$} & $\begin{array}{l}\text { Number of educational } \\
\text { institutions (except for } \\
\text { kindergartens) }\end{array}$ & $\begin{array}{l}\text { Institutions } \\
1000 \\
\text { residents }\end{array}$ & + & 0.1513 & 0.1969 & 0.2831 & 0.9256 & 0.2553 & 0.1897 & 0.2811 & 0.5430 & 0.2588 & 0.5416 & 0.2607 \\
\hline & $\begin{array}{c}\text { Number of places in } \\
\text { kindergartens }\end{array}$ & Number & + & 1679 & 551 & 513 & 1015 & 2067 & 1787 & 1009 & 897 & 1479 & 1002 & 746 \\
\hline & $\begin{array}{l}\text { Number of healthcare } \\
\text { institutions per } \\
1000 \text { residents }\end{array}$ & $\begin{array}{l}\text { Institutions } \\
1000 \\
\text { residents }\end{array}$ & + & 0.1513 & 0.1476 & 0.1887 & 0.4628 & 0.0638 & 0.3319 & 0.4685 & 0.0679 & 0.2804 & 0.2708 & 0.0652 \\
\hline & $\begin{array}{l}\text { Recreational facilities in } \\
\text { the neighborhood per } \\
1000 \text { residents }\end{array}$ & $\begin{array}{l}\text { Institutions } \\
1000 \\
\text { residents }\end{array}$ & + & 0.0908 & 0.3445 & 0.0944 & 0.8227 & 0.1596 & 0.0948 & 0.0937 & 0.4751 & 0.2157 & 0.7221 & 0.3911 \\
\hline & $\begin{array}{l}\text { Annual crime rate per } \\
1000 \text { residents }\end{array}$ & Number & - & 5.9595 & 4.5276 & 13.7775 & 13.421 & 5.9681 & 5.9983 & 11.1965 & 6.7195 & 5.9737 & 7.2207 & 13.9486 \\
\hline \multirow{4}{*}{$\begin{array}{l}\text { Environmental } \\
\text { factors }\end{array}$} & Air pollution $\mathrm{NO}_{2}$ & $\mu \mathrm{g} / \mathrm{m}^{3}$ & - & 11.00 & 11.20 & 29.16 & 15.36 & 13.47 & 11.07 & 11.90 & 10.07 & 26.37 & 23.92 & 33.72 \\
\hline & Noise & $\mathrm{dB}$ & - & 48.34 & 49.55 & 52.43 & 54.96 & 52.68 & 31.82 & 53.72 & 45.64 & 57.69 & 49.17 & 41.56 \\
\hline & Distance to the city center & $\mathrm{Km}$ & - & 5.9 & 7.1 & 2.5 & 1.6 & 3.7 & 4.9 & 2.9 & 5.7 & 5.6 & 1.2 & 2.3 \\
\hline & $\begin{array}{l}\text { Green spaces (maintained } \\
\text { large parks and small } \\
\text { green urban spaces) }\end{array}$ & $\%$ & + & 4.48 & 0.04 & 7.37 & 21.66 & 8.67 & 20.03 & 17.80 & 10.75 & 2.78 & 1.77 & 0.21 \\
\hline
\end{tabular}

* The sign $+(-)$ indicates that a greater (lesser) criterion value corresponds to a greater (lesser) significance for stakeholders. 


\section{The Criteria Weights' Determination Methods}

The MCDM methods involve the decision matrix $R=\left\|r_{i j}\right\|$, statistical data on the criteria or expert judgements, and the vector of criteria significances (weights) $\Omega=\left(\omega_{j}\right)$, where $i=1,2, \ldots, n$; $j=1,2, \ldots, m ; m$ denote the number of criteria; $n$ is the number of the compared alternatives.

Criteria weights may be objective or subjective. As the criteria are assessed, the data structure can be evaluated, and the real prevalence, or the objective weight, of each criteria is determined. Combination weighting is based on the integration of subjective weighting and objective weighting $[20,75,76]$. In this research, we use such methods as entropy, the Criterion Impact Loss (CILOS) and the Integrated Determination of Objective Criteria Weights (IDOCRIW) (Section 5.1). Subjective weights based on expert judgement are, however, more common in practice [77]. Subjective criteria weights, as overall averages of expert opinions, may be applied in a multiple criteria assessment if the expert opinions are in concordance. Section 5.2 presents how the subjective weights were determined.

\subsection{Determining the Objective Criteria Weights}

\subsubsection{The Entropy Method}

The entropy method was offered by Shannon [78]. Entropy weights are defined as follows $[20,76,79]$ :

The criteria values are normalized using Equation (1):

$$
\widetilde{r}_{i j}=\frac{r_{i j}}{\sum_{i=1}^{n} r_{i j}}
$$

The entropy level of each criteria is calculated as follows:

$$
E_{j}=-\frac{1}{\ln n} \sum_{i=1}^{n} \widetilde{r}_{i j} \cdot \ln \widetilde{r}_{i j},\left(j=1,2, \ldots, m ; 0 \leq E_{j} \leq 1\right),
$$

The degree of diversification of each criteria $j$ is calculated:

$$
d_{j}=1-E_{j}
$$

The entropy weights are calculated as $d_{j}$ normalized values:

$$
W_{j}=\frac{d_{j}}{\sum_{j=1}^{m} d_{j}}
$$

The entropy weights reflect the structure of the data and the degree of their non-homogeneity. The weight of the homogeneous data (when the criteria values do not differ considerably), which is obtained by the entropy method (4), is about zero and does not have a strong influence on the evaluation. The largest weight of the criteria obtained by using the entropy method corresponds to the criteria with the highest weight ratio.

\subsubsection{The Criteria Impact Loss: CILOS Method}

This is another promising criteria impact loss method and a determination of objective weights [80]. This method evaluates the loss of each criteria, until one of the remaining criteria reaches the optimum. This method's algorithm, formalization, description and application are presented [76]. The logic of this method, the basic ideas, stages and a calculation algorithm are executed by the procedure that is given below. 
The criteria that are minimized are transformed into maximizing ones, according to the following equation:

$$
\bar{r}_{i j}=\frac{\min _{i} r_{i j}}{r_{i j}}
$$

The new matrix is denoted as $\mathrm{X}=\left\|x_{i j}\right\|$. The maximum values of each column (i.e., every criteria) are calculated: $x_{j}=\max _{i} x_{i j}=x_{k_{j} j}$ where the $k_{j} j$-th lines of the column with the largest element number.

A square matrix $A=\left\|a_{i j}\right\|$ is formed from the $k_{j}$-th rows values of matrix $\mathrm{X} ; a_{j j}=x_{j}(i, j=1,2, \ldots$, $m ; m$, number of criteria).

Matrix $P=\left\|p_{i j}\right\|$ of the relative losses is given below:

$$
p_{i j}=\frac{x_{j}-a_{i j}}{x_{j}}\left(p_{i i}=0 ; i, j=1,2, \ldots, m\right)
$$

Elements $p_{i j}$ of the $P$ matrix show what the relative loss of the $j$-th criterion will be, if the $i$-th criterion is selected to be the best.

Weights $q=\left(q_{1}, q_{2}, \ldots, q_{m}\right)$ can be found from the system:

$$
F q=0
$$

where matrix $F$ is as follows:

$$
F=\left(\begin{array}{cccc}
-\sum_{i=1}^{m} p_{i 1} & p_{12} & \ldots & p_{1 m} \\
p_{21} & -\sum_{i=1}^{m} p_{i 2} & & p_{2 m} \\
& \ldots & & \\
p_{m 1} & p_{m 2} & \ldots & -\sum_{i=1}^{m} p_{i m}
\end{array}\right)
$$

The method based on the criteria significance loss offsets the drawback of the entropy method. Thus, when the values of the criteria do not differ considerably, elements $p_{i j}$ of matrix $P$ of the relative loss of the criteria's impact (6) approach zero, while the respective criteria weight increases and has a great impact on the evaluation. In the case of homogeneity, when the values of one of the criteria are the same in all of the alternatives, all of the relative losses of the criteria, as well as their total loss, are equal to zero. Therefore, the linear system of Equation (7) makes no sense because one column of elements in matrix $P$ is equal to zero.

\subsubsection{Aggregate Objective Weights: The IDOCRIW Method}

Using the idea of the different significance weights to connect to a single overall weight [20], it is possible to connect entropy weights $W_{j}$ and weights $q_{j}$ of the criteria impact loss methods to the common objective criteria for the assessment of the structure of the array weights $\omega_{j}$ [76]:

$$
\omega_{j}=\frac{q_{j} W_{j}}{\sum_{j=1}^{m} q_{j} W_{j}}
$$

These weights will emphasize the separation of the particular values of the criteria (entropy characteristic), but the impact of these criteria decreases due the higher loss in the other criteria.

The calculated weights of the entropy and criteria loss of impact are combined into aggregated weights and are then used in the multi-criteria assessment to rank the options and select the best alternative.

\subsection{Determining the Subjective Criteria Weights Based on an Expert Survey}

Most of the currently-known methods applied when determining criteria weights in multiple criteria assessment are based on expert judgement. Assessments by professional experts form the basis 
for subjective criteria weights. The assessments depend on the experts' qualifications, job specifics, interests, work experience, and so on. The method of direct criteria weight determination is applied in research where the sum of the weights of all assessments $c_{j k}$ by each expert must be equal to one (or 100\%).

The direct basis weights of the $j$-th criteria are calculated using the following equation:

$$
w_{j}=\frac{\sum_{k=1}^{r} c_{j k}}{\sum_{j=1}^{m} \sum_{k=1}^{r} c_{j k}}
$$

where $j=1,2, \ldots, m ; m$ is the number of criteria, and $r$ is the number of experts.

Table 7 (in the last column) lists the weights of each environment and criteria.

\subsection{Overall Objective and Subjective Weights}

Once the entropy, CILOS and IDOCRIW methods have produced the objective weights and the expert judgement has produced the subjective weights, the overall weights that make calculations more reliable can be determined.

The overall weights are calculated using Equation (11), which combines subjective weights $w_{j}$ and objective weights $\omega_{j}$ :

$$
\alpha_{j}=\frac{w_{j} \omega_{j}}{\sum_{j=1}^{m} w_{j} \omega_{j}}
$$

Once the criteria weights are known, the multiple criteria assessment using COPRAS, SAW, TOPSIS and EDAS is performed.

\section{The Methods Applied}

\subsection{The COPRAS Method}

The criteria of the COPRAS (Complex Proportional Assessment) method) [22] $Z_{i}$ were calculated as follows:

$$
Z_{i}=S_{+i}+\frac{\sum_{i=1}^{n} S_{-i}}{S_{-i} \sum_{i=1}^{n} \frac{1}{S_{-i}}}
$$

$S_{+i}=\sum_{j=1}^{m} \omega_{j} \widetilde{r}_{+i j}$ is the sum of the weighted values of the maximized criteria $\widetilde{r}_{+i j}$,

$S_{-i}=\sum_{j=1}^{m} \omega_{j} \widetilde{r}_{-i j}$ is same for the minimized criteria, where $\omega_{j}$ is the weight of the $j$-th criteria, and $\widetilde{r}_{i j}$ is normalized by using Equation (1), the value of the $j$-th criteria for the $i$-th alternative.

\subsection{The SAW Method}

The basic idea behind the MCDM methods is to combine the criteria values and weights to obtain a single point of reference for evaluation, i.e., the method's criteria. A common example is SAW [81], where the method's evaluation criteria $S_{i}$ are calculated by using Equation (13):

$$
S_{i}=\sum_{j=1}^{m} \omega_{j} \widetilde{r}_{i j}
$$

where $\omega_{j}$ is the weight of the $j$-th criteria and $\widetilde{r}_{i j}$ is normalized by using Equation (1), the value of the $j$-th criteria for the $i$-th alternative. 


\subsection{The TOPSIS Method}

The TOPSIS method [20] is based on vector normalization:

$$
\widetilde{r}_{i j}=\frac{r_{i j}}{\sqrt{\sum_{i=1}^{n} r_{i j}^{2}}}(i=1, \ldots, n ; j=1, \ldots, m)
$$

where $\widetilde{r}_{i j}$ is the normalized value of the $j$-th criteria for the $i$-th alternative.

The best alternative $V^{*}$ and the worst alternative $V^{-}$were calculated by:

$$
\begin{gathered}
V *=\left\{V_{1}^{*}, V_{2}^{*}, \ldots, V_{m}^{*}\right\}=\left\{\left(\max _{i} \omega_{j} \widetilde{r}_{i j} / j \in J_{1}\right),\left(\min _{i} \omega_{j} \widetilde{r}_{i j} / j \in J_{2}\right)\right\}, \\
V^{-}=\left\{V_{1}^{-}, V_{2}^{-}, \ldots, V_{m}^{-}\right\}=\left\{\left(\left(\min _{i} \omega_{j} \widetilde{r}_{i j} / j \in J_{1}\right),\left(\left(\max _{i} \omega_{j} \widetilde{r}_{i j} / j \in J_{2}\right)\right\},\right.\right.
\end{gathered}
$$

where $J_{1}$ is a set of indices of the maximized criteria and $J_{2}$ is a set of indices of the minimized criteria.

Distance $D_{i}^{*}$ of every considered alternative to the ideal (best) solutions and its distance $D_{i}^{-}$to the worst solutions were calculated by:

$$
\begin{gathered}
D_{i}^{*}=\sqrt{\sum_{j=1}^{m}\left(\omega_{j} \widetilde{r}_{i j}-V_{j}^{*}\right)^{2}} \\
D_{i}^{-}=\sqrt{\sum_{j=1}^{m}\left(\omega_{j} \widetilde{r}_{i j}-V_{j}^{-}\right)^{2}}
\end{gathered}
$$

Criteria $C_{i}^{*}$ of the method TOPSIS were calculated by:

$$
C_{i}^{*}=\frac{D_{i}^{-}}{D_{i}^{*}+D_{i}^{-}}(i=1, \ldots, n)
$$

$\left(0 \leq C_{i}^{*} \leq 1\right)$

\subsection{The EDAS Method}

The EDAS (Evaluation Based on Distance from Average Solution) method is similar to the TOPSIS method. In the EDAS method, the best alternative is related to the distance from the average solution [21]. In this method, the authors have two measures dealing with the desirability of the alternatives. The first measure is the Positive Distance from the average (PD), and the second is the Negative Distance from the average (ND). The evaluation of the alternatives is made according to higher values of PD and lower values of ND. The steps for using the EDAS method are presented as follows:

Step 1: Construct the decisions matrix (R):

$$
R=\left\|r_{i j}\right\|,
$$

and the criteria weights vector:

$$
\Omega=\left(\omega_{j}\right),
$$

Step 2: Calculate the average of all of the criteria:

$$
A V_{j}=\sum_{i=1}^{n} r_{i j} / n
$$


Step 3: Calculate the positive distance $(P D)$ and the negative distance $(N D)$ from the average:

$$
\begin{aligned}
P D_{i j} & =\frac{\max \left(0,\left(r_{i j}-A V_{j}\right)\right)}{A V_{j}} \\
N D_{i j} & =\frac{\max \left(0,\left(A V_{j}-r_{i j}\right)\right)}{A V_{j}}
\end{aligned}
$$

The $j$-th criteria are maximized, and:

$$
\begin{aligned}
P D_{i j} & =\frac{\max \left(0,\left(A V_{j}-r_{i j}\right)\right)}{A V_{j}} \\
N D_{i j} & =\frac{\max \left(0,\left(r_{i j}-A V_{j}\right)\right)}{A V_{j}}
\end{aligned}
$$

The $j$-th criteria are minimized.

Step 4: Determine the weighted sum of $P D$ and $N D$ for all of the alternatives:

$$
\begin{aligned}
S P_{i} & =\sum_{j=1}^{m} \omega_{j} P D_{i j} \\
S N_{i} & =\sum_{j=1}^{m} \omega_{j} N D_{i j}
\end{aligned}
$$

Step 5: Normalize the values of $S P$ and $S N$ for all of the alternatives:

$$
\begin{gathered}
N S P_{i}=\frac{S P_{i}}{\max _{i} S P_{i}} \\
N S N_{i}=1-\frac{S N_{i}}{\max _{i} S N_{i}}
\end{gathered}
$$

Step 6: Calculate the appraisal score $(A S)$ for all of the alternatives:

$$
A S_{i}=\frac{1}{2}\left(N S P_{i}+N S N_{i}\right)
$$

where $0 \leq A S_{i} \leq 1$

\subsection{Borda Count and Copeland's Methods}

Different MCDM methods usually produce different assessment results (ranks). The Borda count $[82,83]$ and Copeland's method $[84,85]$ can be used as tools for the ranking of alternatives based on all MCDM assessments. The two methods use the following calculation algorithm:

1. A matrix for the assessment (ranking) $S_{i j}(i=\overline{1, n} ; j=\overline{1, k})$ of alternatives $\left(a_{1}, a_{2}, \ldots, a_{n}\right)$ is built with the methods $\mathrm{M}_{1}, \mathrm{M}_{2}, \ldots, \mathrm{M}_{k}$ applied (Table 5). The average ranking $S_{1}, S_{2}, \ldots, S_{n}$ for each alternative is calculated.

2. The average rankings are then used for paired comparison of the rationality of all alternatives to determine which alternative has the lower average. Matrix B for the comparison of alternatives is built (Table 6). The alternatives compared in the matrix score either one or zero, where one signifies that the alternative in that row is more rational than the alternative in that column, and zero signifies that the alternative is not more rational or they both are equally rational.

3. The relative rationality values of each alternative (neighborhood) are added together horizontally $\left(P_{i}\right)$. 
4. The relative rationality values of each alternative (neighborhood) are added together vertically $\left(N_{j}\right)$, and the alternative's "losses" are calculated.

5. The rational alternative:

- Is the one that corresponds to the largest term of the last column in Matrix $B$ in the case of the Borda method $[82,83]$;

- Is the alternative that produces the largest value when the "losses" $\left(N_{j}\right)$ are subtracted from the sum of its rationalities $\left(P_{i}\right)$ in case of Copeland's method [84,85].

Table 5. The ranks and their averages produced by different MCDM methods.

\begin{tabular}{|c|c|c|c|c|c|c|}
\hline Alternatives & Methods & $\mathbf{M}_{1}$ & $\mathbf{M}_{2}$ & $\cdots$ & $\mathbf{M}_{k}$ & $\begin{array}{l}\text { Average } \\
\text { Ranking }\end{array}$ \\
\hline$a_{1}$ & & $S_{11}$ & $S_{12}$ & $\ldots$ & $S_{1 k}$ & $S_{1}$ \\
\hline$a_{2}$ & & $S_{21}$ & $S_{22}$ & $\ldots$ & $S_{2 k}$ & $S_{2}$ \\
\hline . & & $\ldots$ & $\ldots$ & $\cdots$ & $\ldots$ & $\ldots$ \\
\hline$a_{n}$ & & $S_{n 1}$ & $S_{n 2}$ & $\ldots$ & $S_{n k}$ & $S_{n}$ \\
\hline
\end{tabular}

Table 6. An example of Matrix B.

\begin{tabular}{cccccc}
\hline \multirow{2}{*}{$\begin{array}{c}\text { Alternative } \\
\text { (Neighborhood) }\end{array}$} & \multicolumn{4}{c}{ Alternative (Neighborhood) } & \multirow{2}{*}{$\boldsymbol{P}_{\boldsymbol{i}}$} \\
\cline { 2 - 5 } & $\boldsymbol{a}_{\mathbf{1}}$ & $\boldsymbol{a}_{\mathbf{2}}$ & $\ldots$ & $\boldsymbol{a}_{\boldsymbol{n}}$ & \\
\hline$a_{1}$ & - & $a_{12}$ & $\ldots$ & $a_{1 n}$ & $P_{1}$ \\
$a_{2}$ & $a_{21}$ & - & $\ldots$ & $a_{2 n}$ & $P_{2}$ \\
$\ldots$ & $\ldots$ & $\ldots$ & $\ldots$ & $\ldots$ & $\ldots$ \\
$a_{n}$ & $a_{n 1}$ & $a_{n 2}$ & $\ldots$ & - & $P_{n}$ \\
$N_{j}$ & $N_{1}$ & $N_{2}$ & $\ldots$ & $N_{n}$ & \\
\hline
\end{tabular}

\section{Results Produced by the MCDM Methods}

The questionnaire comprised four stages: an overall assessment of sustainable development areas (the economic environment, the social environment and the environmental dimension), an assessment of the individual factors of the economic environment, an assessment of the individual factors of the social environment and an assessment of the individual factors of the environmental dimension. The criteria were ranked according to their importance for assessment purposes. Table 7 presents the results of the expert judgement. Experts have applied the weights-direct-determination method. Each expert judgment totals $100 \%$. The methodology is described in Section 5.2. The authors use Equation (10).

The Kendall [86] rank correlation theory was applied to verify the concordance of the expert judgement. The assessment was performed using the table of the expert rankings of the criteria. The opinions were in concordance in all of the assessments. The concordance coefficient $W=0.285$ for the assessments of the economic environment and the respective value $\chi^{2}=14.83$ of criteria $\chi^{2}$ is above the critical value $\chi_{k r}^{2}=9.488$ taken from the $\chi^{2}$ distribution table with $v=5-1=4$ degrees of freedom, and the significance $\alpha=0.05$; thus, the concordance of the expert judgement was assumed statistically. For the social environment, the values are $W=0.625, \chi^{2}=36.55\left(\chi_{k r}^{2}=9.488\right)$, and for the environmental dimension, the values are $W=0.346, \chi^{2}=13.50\left(\chi_{k r}^{2}=7.815 ; v=3\right)$. The impact of each environment compared shows $W=0.290, \chi^{2}=7.538\left(\chi_{k r}^{2}=5.991 ; v=2\right)$. To determine the criteria weights, the experts made a direct assessment of their importance, i.e., the sum total of the weights of all assessments $c_{j k}$ by each expert must be equal to one, or $100 \%$. The assessments of the individual criteria may repeat. Tables $8-13$ present the results of the objective, subjective and overall weights determined for each area of sustainable development (economic, social and environmental). 
Table 7. Expert judgement.

\begin{tabular}{|c|c|c|c|c|c|c|c|c|c|c|c|c|c|c|c|}
\hline & Expert & 1 & 2 & 3 & 4 & 5 & 6 & 7 & 8 & 9 & 10 & 11 & 12 & 13 & Subjective \\
\hline & Judgement & $\%$ & $\%$ & $\%$ & $\%$ & $\%$ & $\%$ & $\%$ & $\%$ & $\%$ & $\%$ & $\%$ & $\%$ & $\%$ & Weight \\
\hline \multirow{3}{*}{$\begin{array}{c}\text { Areas of } \\
\text { sustainable } \\
\text { development }\end{array}$} & Economic environment factors & 50 & 45 & 50 & 40 & 35 & 25 & 35 & 45 & 50 & 50 & 50 & 45 & 30 & 0.4231 \\
\hline & Social environment factors & 30 & 30 & 25 & 25 & 25 & 40 & 20 & 20 & 20 & 30 & 15 & 20 & 50 & 0.2692 \\
\hline & Environmental factors & 20 & 25 & 25 & 35 & 40 & 35 & 45 & 35 & 30 & 20 & 35 & 35 & 20 & 0.3077 \\
\hline \multirow{5}{*}{$\begin{array}{c}\text { Economic } \\
\text { environment } \\
\text { factors }\end{array}$} & Housing price $\left(\right.$ Eur $\left./ \mathrm{m}^{2}\right)$ & 10 & 15 & 50 & 40 & 55 & 10 & 35 & 40 & 40 & 25 & 30 & 35 & 35 & 0.3231 \\
\hline & Population density & 30 & 25 & 20 & 25 & 12 & 26 & 20 & 15 & 25 & 15 & 10 & 15 & 18 & 0.1969 \\
\hline & $\begin{array}{l}\text { Density of single-family and } \\
\text { two-family houses }\end{array}$ & 20 & 10 & 5 & 5 & 8 & 19 & 5 & 10 & 5 & 10 & 30 & 20 & 12 & 0.1223 \\
\hline & Density of blocks of flats & 25 & 20 & 20 & 20 & 15 & 31 & 15 & 20 & 20 & 20 & 25 & 20 & 10 & 0.2008 \\
\hline & Number of jobs & 15 & 30 & 5 & 10 & 10 & 14 & 25 & 15 & 10 & 30 & 5 & 10 & 25 & 0.1569 \\
\hline \multirow{5}{*}{$\begin{array}{c}\text { Social } \\
\text { environment } \\
\text { factors }\end{array}$} & $\begin{array}{l}\text { Number of educational institutions } \\
\text { (except for kindergartens) }\end{array}$ & 9 & 30 & 30 & 20 & 15 & 30 & 20 & 15 & 25 & 20 & 20 & 20 & 16 & 0.2077 \\
\hline & Number of places in kindergartens & 20 & 25 & 30 & 25 & 20 & 15 & 15 & 15 & 15 & 22 & 15 & 25 & 14 & 0.1969 \\
\hline & Number of healthcare institutions & 30 & 16 & 5 & 15 & 25 & 20 & 25 & 10 & 15 & 18 & 5 & 5 & 10 & 0.1531 \\
\hline & Number of recreational facilities & 1 & 9 & 5 & 10 & 5 & 10 & 10 & 10 & 10 & 15 & 10 & 10 & 20 & 0.0962 \\
\hline & Annual crime rates & 40 & 20 & 30 & 30 & 35 & 25 & 30 & 50 & 35 & 25 & 50 & 40 & 40 & 0.3462 \\
\hline \multirow{4}{*}{$\begin{array}{l}\text { Environmental } \\
\text { dimension factors }\end{array}$} & Air pollution $\mathrm{NO}_{2}$ & 14 & 20 & 10 & 17 & 20 & 35 & 10 & 15 & 20 & 20 & 30 & 25 & 15 & 0.2238 \\
\hline & Noise & 16 & 35 & 20 & 25 & 30 & 21 & 15 & 30 & 20 & 35 & 30 & 35 & 35 & 0.2669 \\
\hline & Distance to the city center & 50 & 15 & 50 & 23 & 22 & 19 & 35 & 20 & 30 & 20 & 10 & 10 & 20 & 0.2415 \\
\hline & $\begin{array}{l}\text { Green spaces (maintained large parks } \\
\text { and small green urban spaces) }\end{array}$ & 20 & 30 & 20 & 35 & 28 & 25 & 40 & 35 & 30 & 25 & 30 & 30 & 30 & 0.2677 \\
\hline
\end{tabular}


Table 8. Determining the weights of the economic environment criteria.

\begin{tabular}{cccccc}
\hline & Entropy & \multicolumn{2}{c}{ CILOS IDOCRIW } & Subjective Weights & Overall Weights \\
\hline Housing prices & 0.1879 & 0.2132 & 0.2304 & 0.3231 & 0.3478 \\
Population density & 0.2970 & 0.1933 & 0.3303 & 0.1969 & 0.3039 \\
Density of single-family & 0.0308 & 0.3188 & 0.0564 & 0.1223 & 0.0322 \\
and two-family houses & 0.2196 & 0.1369 & 0.1729 & 0.2008 & 0.1622 \\
Density of blocks of flats & 0.2648 & 0.1378 & 0.2099 & 0.1569 & 0.1539 \\
Number of jobs & & &
\end{tabular}

In Tables 8, 10 and 12, the weight was calculated using the following equations: entropy (1)-(4), CILOS (5)-(8), IDOCRIW (9), subjective weights (10) and overall weights (11). The overall ranking in Tables 9, 11 and 13 was determined by using the "sum of ranks" (the lower the sum of ranks is, the better ranking the neighborhood has).

For the economic environment, price (0.3478) and population density (0.3039) have the biggest impact on the assessments of a healthy and safe built environment (Table 8). The density of single-family and apartment buildings has the lowest impact (0.0322).

The Vilnius neighborhoods were assessed with the MCDM methods (TOPSIS, COPRAS, SAW and EDAS) using the overall weights. Table 9 sums up the assessment results of the economic environment in the Vilnius neighborhoods for all four MCDM methods. There are minor variations in the priority rankings for TOPSIS, COPRAS, SAW and EDAS. The overall rankings were calculated by adding together the rankings produced by each method. The results were verified using the rank average, Borda count and Copeland's methods [20,82-85]. Notably, all of the assessments produced by these methods matched. The calculations suggest that in terms of the economic environment, Naujamiestis is seen as being the best alternative, followed by Senamiestis and then Paneriai.

The objective, subjective and overall weights of the social environment criteria show that the number of medical institutions has the biggest impact (0.3424), followed by the number of crimes (0.3069) (Table 10). It follows that these criteria are directly related to the assessment of a healthy and safe environment.

After the multiple criteria assessment of 21 neighborhoods in Vilnius using COPRAS, SAW, TOPSIS and EDAS and the verification of the results using the rank average, Borda count and Copeland's methods (Table 11), the priority rankings looked similar. In terms of the social criteria, Senamiestis came first, followed by Antakalnis and then Žvèrynas.

The objective and subjective criteria weights determined for the environmental dimension show some differences (Table 12). The weights determined using the entropy, CILOS and IDOCRIW methods identify different key criteria from those that are compared. When using the entropy method, for instance, proximity to the city center has the biggest weight, while when using the CILOS method, green spaces come on top. The subjective weights determined by the expert judgement are all very similar. Presumably, the experts believe that all of the criteria are important in the assessment of a healthy and safe environment. The overall weights highlight two key criteria that affect the assessment of a healthy and safe built environment; green spaces (0.4976) and air pollution (0.3179).

In terms of the environmental dimension, Senamiestis again ranked best out of the other neighborhoods (Table 13). Senamiestis has plenty of green spaces (Kalnai Park, Bernardinai Garden, Cvirka Square, Kūdros Park and many others), and few other neighborhoods are closer to the city center. The Verkiai neighborhood comes second, followed by Vilkpèdè. 
Table 9. The assessment of the economic environment using the MCDM methods.

\begin{tabular}{|c|c|c|c|c|c|c|c|c|c|c|c|c|c|}
\hline & \multirow{2}{*}{$\begin{array}{c}\text { COPRAS } \\
\text { The Values of } \\
\text { the Assessment } \\
\text { Criteria }\end{array}$} & \multirow[b]{2}{*}{ Rank } & \multirow{2}{*}{$\begin{array}{c}\text { SAW } \\
\text { The Values of } \\
\text { the Assessment } \\
\text { Criteria }\end{array}$} & \multirow[b]{2}{*}{ Rank } & \multicolumn{2}{|l|}{ TOPSIS } & \multicolumn{2}{|l|}{ EDAS } & \multirow[b]{2}{*}{$\begin{array}{l}\text { Sum of } \\
\text { Ranks }\end{array}$} & \multirow[b]{2}{*}{$\begin{array}{c}\text { Overall } \\
\text { Ranking }\end{array}$} & \multirow{2}{*}{$\begin{array}{c}\text { Rank } \\
\text { Average } \\
\text { Ranking }\end{array}$} & \multirow{2}{*}{$\begin{array}{c}\text { Borda } \\
\text { Count } \\
\text { Ranking }\end{array}$} & \multirow[b]{2}{*}{$\begin{array}{c}\text { Cope-Land } \\
\text { Ranking }\end{array}$} \\
\hline & & & & & $\begin{array}{c}\text { The Values of } \\
\text { the Assessment } \\
\text { Criteria }\end{array}$ & Rank & $\begin{array}{c}\text { The Values of } \\
\text { the Assessment } \\
\text { Criteria }\end{array}$ & Rank & & & & & \\
\hline 1. Antakalnis & 0.0545 & 8 & 0.0551 & 7 & 0.3260 & 10 & 0.5107 & 10 & 35 & 9 & 9 & 9 & 9 \\
\hline 2. Fabijoniškès & 0.0332 & 15 & 0.0330 & 12 & 0.2611 & 17 & 0.2910 & 17 & 61 & 15 & 15 & 15 & 15 \\
\hline 3. Grigiškès & 0.0338 & 13 & 0.0291 & 14 & 0.2930 & 12 & 0.4257 & 13 & 52 & 13 & 13 & 13 & 13 \\
\hline 4. Justiniškès & 0.0146 & 21 & 0.0149 & 21 & 0.0739 & 21 & 0.0023 & 21 & 84 & 21 & 21 & 21 & 21 \\
\hline 5. Karoliniškès & 0.0147 & 20 & 0.0151 & 19 & 0.2139 & 18 & 0.2217 & 19 & 76 & 19 & 19 & 19 & 19 \\
\hline 6. Lazdynai & 0.0283 & 17 & 0.0251 & 17 & 0.2682 & 16 & 0.3908 & 16 & 66 & 17 & 17 & 17 & 17 \\
\hline 7. Naujamiestis & 0.1008 & 2 & 0.0990 & 2 & 0.6708 & 1 & 0.9485 & 1 & 6 & 1 & 1 & 1 & 1 \\
\hline 8. Naujininkai & 0.0546 & 7 & 0.0458 & 8 & 0.3282 & 9 & 0.5235 & 8 & 32 & $7-8$ & $7-8$ & $7-8$ & $7-8$ \\
\hline 9. Naujoji Vilnia & 0.0538 & 9 & 0.0456 & 9 & 0.3400 & 7 & 0.5423 & 7 & 32 & $7-8$ & $7-8$ & $7-8$ & $7-8$ \\
\hline 10. Paneriai & 0.1200 & 1 & 0.1753 & 1 & 0.3984 & 5 & 0.6175 & 3 & 10 & $2-3$ & $2-3$ & $2-3$ & $2-3$ \\
\hline 11. Pašilaičiai & 0.0336 & 14 & 0.0316 & 13 & 0.2900 & 13 & 0.4462 & 11 & 51 & 12 & 12 & 12 & 12 \\
\hline 12. Pilaitė & 0.0348 & 12 & 0.0290 & 15 & 0.2850 & 14 & 0.4082 & 14 & 55 & 14 & 14 & 14 & 14 \\
\hline 13. Rasos & 0.0476 & 10 & 0.0425 & 10 & 0.3391 & 8 & 0.5201 & 9 & 37 & 10 & 10 & 10 & 10 \\
\hline 14. Senamiestis & 0.0813 & 3 & 0.0796 & 3 & 0.5864 & 2 & 0.7827 & 2 & 10 & $2-3$ & $2-3$ & $2-3$ & $2-3$ \\
\hline 15. Šeškinė & 0.0232 & 18 & 0.0226 & 18 & 0.1906 & 19 & 0.2514 & 18 & 73 & 18 & 18 & 18 & 18 \\
\hline 16. Verkiai & 0.0599 & 6 & 0.0543 & 5 & 0.3596 & 6 & 0.5917 & 4 & 21 & 6 & 6 & 6 & 6 \\
\hline 17. Vilkpèdè & 0.0300 & 16 & 0.0254 & 16 & 0.2731 & 15 & 0.3947 & 15 & 62 & 16 & 16 & 16 & 16 \\
\hline 18. Viršuliškès & 0.0161 & 19 & 0.0150 & 20 & 0.1862 & 20 & 0.2209 & 20 & 79 & 20 & 20 & 20 & 20 \\
\hline 19. Žirmūnai & 0.0394 & 11 & 0.0377 & 11 & 0.3208 & 11 & 0.4402 & 12 & 45 & 11 & 11 & 11 & 11 \\
\hline 20. Žvėrynas & 0.0656 & 4 & 0.0649 & 4 & 0.4774 & 3 & 0.5652 & 6 & 17 & 4 & 4 & 4 & 4 \\
\hline 21. Šnipiškès & 0.0603 & 5 & 0.0592 & 6 & 0.4416 & 4 & 0.5737 & 5 & 20 & 5 & 5 & 5 & 5 \\
\hline
\end{tabular}

Table 10. Determining the weights of the social environment criteria.

\begin{tabular}{|c|c|c|c|c|c|}
\hline & Entropy & CILOS & IDOCRIW & Subjective Weights & Overall Weights \\
\hline $\begin{array}{c}\text { Number of educational institutions (except for } \\
\text { kindergartens) }\end{array}$ & 0.1185 & 0.1924 & 0.1180 & 0.2077 & 0.1342 \\
\hline Number of places in kindergartens & 0.1439 & 0.1277 & 0.0951 & 0.1969 & 0.1025 \\
\hline Number of recreational facilities & 0.3546 & 0.1180 & 0.2165 & 0.0962 & 0.1140 \\
\hline Annual crime rate per 1000 residents & 0.1192 & 0.2626 & 0.1619 & 0.3462 & 0.3069 \\
\hline
\end{tabular}


Table 11. The assessment of the social environment using the MCDM methods.

\begin{tabular}{|c|c|c|c|c|c|c|c|c|c|c|c|c|c|}
\hline & \multicolumn{2}{|c|}{ COPRAS } & \multicolumn{2}{|l|}{ SAW } & \multicolumn{2}{|l|}{ TOPSIS } & \multicolumn{2}{|l|}{ EDAS } & \multirow[b]{2}{*}{$\begin{array}{l}\text { Sum of } \\
\text { Ranks }\end{array}$} & \multirow[b]{2}{*}{$\begin{array}{c}\text { Overall } \\
\text { Ranking }\end{array}$} & \multirow{2}{*}{$\begin{array}{c}\text { Rank } \\
\text { Average } \\
\text { Ranking }\end{array}$} & \multirow{2}{*}{$\begin{array}{c}\text { Borda } \\
\text { Count } \\
\text { Ranking }\end{array}$} & \multirow[b]{2}{*}{$\begin{array}{c}\text { Cope-land } \\
\text { Ranking }\end{array}$} \\
\hline & $\begin{array}{l}\text { The Values of } \\
\text { the Assessment } \\
\text { Criteria }\end{array}$ & Rank & $\begin{array}{c}\text { The Values of } \\
\text { the Assessment } \\
\text { Criteria }\end{array}$ & Rank & $\begin{array}{l}\text { The Values of } \\
\text { the Assessment } \\
\text { Criteria }\end{array}$ & Rank & $\begin{array}{c}\text { The Values of } \\
\text { the Assessment } \\
\text { Criteria }\end{array}$ & Rank & & & & & \\
\hline 1. Antakalnis & 0.0706 & 2 & 0.0706 & 2 & 0.6994 & 1 & 0.7816 & 2 & 7 & 2 & 2 & 2 & 2 \\
\hline 2. Fabijoniškès & 0.0381 & 17 & 0.0381 & 16 & 0.3556 & 17 & 0.2984 & 17 & 67 & 17 & 17 & $17-18$ & 17 \\
\hline 3. Grigiškès & 0.0437 & 12 & 0.0437 & 12 & 0.3816 & 13 & 0.3710 & 11 & 48 & 12 & 12 & $13-14$ & $12-13$ \\
\hline 4. Justiniškès & 0.0511 & 8 & 0.0511 & 8 & 0.4556 & 8 & 0.4906 & 8 & 32 & 8 & 8 & 8 & 8 \\
\hline 5. Karoliniškès & 0.0438 & 11 & 0.0438 & 11 & 0.3862 & 12 & 0.3908 & 10 & 44 & 11 & 11 & 11 & 11 \\
\hline 6. Lazdynai & 0.0463 & 10 & 0.0463 & 10 & 0.4006 & 10 & 0.3703 & 12 & 42 & 10 & 10 & 10 & 10 \\
\hline 7. Naujamiestis & 0.0579 & 4 & 0.0579 & 4 & 0.5358 & 7 & 0.5575 & 6 & 21 & 5 & 5 & 5 & 5 \\
\hline 8. Naujininkai & 0.0316 & 19 & 0.0316 & 19 & 0.1872 & 20 & 0.0895 & 20 & 78 & $19-20$ & $19-20$ & $19-20$ & $19-20$ \\
\hline 9. Naujoji Vilnia & 0.0356 & 18 & 0.0356 & 18 & 0.2984 & 18 & 0.2782 & 18 & 72 & 18 & 18 & $17-18$ & 18 \\
\hline 10. Paneriai & 0.0425 & 13 & 0.0425 & 13 & 0.3752 & 14 & 0.3054 & 15 & 55 & 14 & 14 & $13-14$ & 14 \\
\hline 11. Pašilaičiai & 0.0419 & 15 & 0.0419 & 15 & 0.3970 & 11 & 0.3620 & 13 & 54 & 13 & 13 & 12 & $12-13$ \\
\hline 12. Pilaitė & 0.0471 & 9 & 0.0471 & 9 & 0.4205 & 9 & 0.3914 & 9 & 36 & 9 & 9 & 9 & 9 \\
\hline 13. Rasos & 0.0307 & 20 & 0.0307 & 20 & 0.2363 & 19 & 0.1129 & 19 & 78 & $19-20$ & $19-20$ & $19-20$ & $19-20$ \\
\hline 14. Senamiestis & 0.0781 & 1 & 0.0781 & 1 & 0.6718 & 2 & 0.8023 & 1 & 5 & 1 & 1 & 1 & 1 \\
\hline 15. Šeškinė & 0.0397 & 16 & 0.0357 & 17 & 0.3613 & 15 & 0.3038 & 16 & 64 & 16 & 16 & 16 & 16 \\
\hline 16. Verkiai & 0.0571 & 5 & 0.0571 & 5 & 0.5810 & 5 & 0.5977 & 4 & 19 & 4 & 4 & 4 & 4 \\
\hline 17. Vilkpèdè & 0.0569 & 6 & 0.0569 & 6 & 0.6043 & 3 & 0.5507 & 7 & 22 & 6 & 6 & 6 & 6 \\
\hline 18. Viršuliškès & 0.0423 & 14 & 0.0423 & 14 & 0.3593 & 16 & 0.3617 & 14 & 58 & 15 & 15 & 15 & 15 \\
\hline 19. Žirmūnai & 0.0549 & 7 & 0.0549 & 7 & 0.5422 & 6 & 0.5931 & 5 & 25 & 7 & 7 & 7 & 7 \\
\hline 20. Žvẻrynas & 0.0625 & 3 & 0.0625 & 3 & 0.5862 & 4 & 0.7127 & 3 & 13 & 3 & 3 & 3 & 3 \\
\hline 21. Šnipiškès & 0.0277 & 21 & 0.0277 & 21 & 0.1507 & 21 & 0.0293 & 21 & 84 & 21 & 21 & 21 & 21 \\
\hline
\end{tabular}

Table 12. Determining the weights of the environmental criteria.

\begin{tabular}{cccccc}
\hline & Entropy & CILOS & IDOCRIW & Subjective Weights & Overall Weights \\
\hline Air pollution $\mathrm{NO}_{2}$ & 0.2470 & 0.2934 & 0.3520 & 0.2238 & 0.3179 \\
\hline Noise & 0.2517 & 0.0147 & 0.0180 & 0.2669 & 0.0194 \\
\hline Distance to the city center & 0.3403 & 0.1026 & 0.1695 & 0.2415 & 0.1652 \\
\hline $\begin{array}{c}\text { Green spaces (maintained large parks and small } \\
\text { green urban spaces) }\end{array}$ & 0.1609 & 0.5894 & 0.1606 & 0.2677 & 0.4976 \\
\hline
\end{tabular}


Table 13. The assessment of the environmental dimension using the MCDM methods.

\begin{tabular}{|c|c|c|c|c|c|c|c|c|c|c|c|c|c|}
\hline & \multirow{2}{*}{$\begin{array}{c}\text { COPRAS } \\
\text { The Values of } \\
\text { the Assessment } \\
\text { Criteria }\end{array}$} & \multirow[b]{2}{*}{ Rank } & \multirow{2}{*}{$\begin{array}{c}\text { SAW } \\
\text { The Values of } \\
\text { the Assessment } \\
\text { Criteria }\end{array}$} & \multirow[b]{2}{*}{ Rank } & \multicolumn{2}{|l|}{ TOPSIS } & \multicolumn{2}{|l|}{ EDAS } & \multirow[b]{2}{*}{$\begin{array}{c}\text { Sum of } \\
\text { Ranks }\end{array}$} & \multirow[b]{2}{*}{$\begin{array}{c}\text { Overall } \\
\text { Ranking }\end{array}$} & \multirow{2}{*}{$\begin{array}{c}\text { Rank } \\
\text { Average } \\
\text { Ranking }\end{array}$} & \multirow{2}{*}{$\begin{array}{c}\text { Borda } \\
\text { Count } \\
\text { Ranking }\end{array}$} & \multirow[b]{2}{*}{$\begin{array}{c}\text { Cope-Land } \\
\text { Ranking }\end{array}$} \\
\hline & & & & & $\begin{array}{l}\text { The Values of } \\
\text { the Assessment } \\
\text { Criteria }\end{array}$ & Rank & $\begin{array}{l}\text { The Values of } \\
\text { the Assessment } \\
\text { Criteria }\end{array}$ & Rank & & & & & \\
\hline 1. Antakalnis & 0.0518 & 7 & 0.0476 & 10 & 0.4717 & 8 & 0.5524 & 7 & 32 & 8 & 8 & 8 & 8 \\
\hline 2. Fabijoniškès & 0.0626 & 5 & 0.0589 & 5 & 0.5891 & 4 & 0.6357 & 5 & 19 & 5 & 5 & 5 & 5 \\
\hline 3. Grigiškès & 0.0128 & 21 & 0.0171 & 21 & 0.1214 & 21 & 0.0159 & 21 & 84 & 21 & 21 & 21 & 21 \\
\hline 4. Justiniškès & 0.0277 & 15 & 0.0279 & 15 & 0.3467 & 16 & 0.3344 & 15 & 61 & 16 & 16 & 16 & 16 \\
\hline 5. Karoliniškès & 0.0453 & 10 & 0.0423 & 11 & 0.4556 & 9 & 0.4972 & 9 & 39 & 9 & 9 & 9 & 9 \\
\hline 6. Lazdynai & 0.0244 & $16-17$ & 0.0222 & 18 & 0.3385 & 17 & 0.2738 & 17 & 68.5 & 17 & 17 & 17 & 17 \\
\hline 7. Naujamiestis & 0.0456 & 9 & 0.0495 & 9 & 0.4208 & 11 & 0.4126 & 11 & 40 & 10 & 10 & $10-11$ & 10 \\
\hline 8. Naujininkai & 0.0341 & 13 & 0.0293 & 14 & 0.3815 & 14 & 0.3657 & 13 & 54 & 13 & 13 & 13 & 13 \\
\hline 9. Naujoji Vilnia & 0.0244 & $16-17$ & 0.0240 & 17 & 0.2527 & 19 & 0.2359 & 19 & 71.5 & 18 & 19 & 19 & 19 \\
\hline 10. Paneriai & 0.0157 & 20 & 0.0172 & 20 & 0.1882 & 20 & 0.1360 & 20 & 80 & 20 & 20 & 20 & 12 \\
\hline 11. Pašilaičiai & 0.0402 & 11 & 0.0379 & 12 & 0.4093 & 12 & 0.4553 & 10 & 45 & 12 & 12 & 12 & 30 \\
\hline 12. Pilaitė & 0.0206 & 19 & 0.0196 & 19 & 0.3209 & 18 & 0.2682 & 16 & 72 & 19 & 18 & 18 & 18 \\
\hline 13. Rasos & 0.0514 & 8 & 0.0546 & 8 & 0.5101 & 7 & 0.5369 & 8 & 31 & 7 & 7 & 7 & 7 \\
\hline 14. Senamiestis & 0.1214 & 1 & 0.1238 & 1 & 0.9604 & 1 & 0.9997 & 1 & 4 & 1 & 1 & 1 & 1 \\
\hline 15. Šeškinè & 0.0621 & 6 & 0.0570 & 6 & 0.5407 & 6 & 0.6152 & 6 & 24 & 6 & 6 & 6 & 6 \\
\hline 16. Verkiai & 0.1016 & 3 & 0.0979 & 2 & 0.8758 & 2 & 0.9158 & 2 & 9 & 2 & 2 & 2 & 2 \\
\hline 17. Vilkpèdè & 0.1019 & 2 & 0.0961 & 3 & 0.8446 & 3 & 0.8835 & 3 & 11 & 3 & 3 & 3 & 3 \\
\hline 18. Viršuliškès & 0.0646 & 4 & 0.0625 & 4 & 0.5787 & 5 & 0.6500 & 4 & 17 & 4 & 4 & 4 & 4 \\
\hline 19. Žirmūnai & 0.0284 & 14 & 0.0256 & 16 & 0.3700 & 15 & 0.3385 & 11 & 56 & $14-15$ & $14-15$ & $14-15$ & 15 \\
\hline 20. Žvèrynas & 0.0400 & 12 & 0.0590 & 7 & 0.4212 & 10 & 0.3887 & 14 & 43 & 11 & 11 & $10-11$ & 11 \\
\hline 21. Šnipiškès & 0.0234 & 18 & 0.0297 & 13 & 0.3830 & 13 & 0.2725 & 12 & 56 & $14-15$ & $14-15$ & $14-15$ & 14 \\
\hline
\end{tabular}


Calculations suggest that 21 neighborhoods in Vilnius rank very differently according to the economic, social and environmental criteria. This is only natural. The Antakalnis neighborhood, for instance, ranks ninth according to its economic environment, second according to its social environment and eighth according to its environmental dimension. The impact of each environment on the overall assessment varies. The overall weight given by 13 experts to the economic environment is $\omega_{1}=0.4231$. The value is $\omega_{2}=0.2692$ for the social environment and $\omega_{3}=0.3077$ for the environmental dimension. With subjective weights, the individual MCDM methods are combined for neighborhood assessments. This time, the decision matrixes contain the criteria values produced by the individual MCDM methods for the economic environment, the social environment and the environmental dimension. All of the methods in this research rank the highest value as the best, which means that all of the criteria are maximizing. Hence, the rankings produced by SAW and COPRAS match. Next, the economic environment, the social environment and the environmental dimension were assessed and the overall ranking produced using COPRAS, SAW, TOPSIS and EDAS. Now let us look at the results produced by the EDAS methods as an example (Table 14). Using COPRAS, SAW and TOPSIS, the results were calculated likewise.

Table 14. EDAS assessments for the economic environment, the social environment, the environmental dimension and the overall rankings.

\begin{tabular}{|c|c|c|c|c|c|}
\hline & $\begin{array}{c}\text { Economic } \\
\text { Environment } \\
\text { Factors } \\
\omega_{1}=\mathbf{0 . 4 2 3 1}\end{array}$ & $\begin{array}{c}\text { Social } \\
\text { Environmen } t \\
\text { Factors } \\
\omega_{2}=0.2692\end{array}$ & $\begin{array}{c}\text { Environmental } \\
\text { Factors } \\
\omega_{3}=0.3077\end{array}$ & $\begin{array}{l}\text { EDASThe Overall } \\
\text { Values of the } \\
\text { Assessment } \\
\text { Criteria }\end{array}$ & $\begin{array}{c}\text { Overall } \\
\text { Rank }\end{array}$ \\
\hline 1. Antakalnis & 0.5107 & 0.7816 & 0.5524 & 0.6888 & 4 \\
\hline 2. Fabijoniškès & 0.2910 & 0.2984 & 0.6357 & 0.3339 & 10 \\
\hline 3. Grigiškès & 0.4257 & 0.3710 & 0.0159 & 0.1469 & 20 \\
\hline 4. Justiniškès & 0.0023 & 0.4906 & 0.3344 & 0.0266 & 21 \\
\hline 5. Karoliniškès & 0.2217 & 0.3908 & 0.4972 & 0.2790 & 17 \\
\hline 6. Lazdynai & 0.3908 & 0.3703 & 0.2738 & 0.2826 & 16 \\
\hline 7. Naujamiestis & 0.9485 & 0.5575 & 0.4126 & 0.7658 & 3 \\
\hline 8. Naujininkai & 0.5235 & 0.0895 & 0.3657 & 0.2590 & 18 \\
\hline 9. Naujoji Vilnia & 0.5423 & 0.2782 & 0.2359 & 0.3042 & 13 \\
\hline 10. Paneriai & 0.6175 & 0.3054 & 0.1360 & 0.2951 & 14 \\
\hline 11. Pašilaičiai & 0.4462 & 0.3620 & 0.4553 & 0.4454 & 8 \\
\hline 12. Pilaitè & 0.4082 & 0.3914 & 0.2682 & 0.3081 & 12 \\
\hline 13. Rasos & 0.5201 & 0.1129 & 0.5369 & 0.3634 & 9 \\
\hline 14. Senamiestis & 0.7827 & 0.8023 & 0.9997 & 1.0000 & 1 \\
\hline 15. Šeškinè & 0.2514 & 0.3038 & 0.6152 & 0.2940 & 15 \\
\hline 16. Verkiai & 0.5917 & 0.5977 & 0.9158 & 0.7978 & 2 \\
\hline 17. Vilkpèdè & 0.3947 & 0.5507 & 0.8835 & 0.6423 & 5 \\
\hline 18. Viršuliškès & 0.2209 & 0.3617 & 0.6500 & 0.3160 & 11 \\
\hline 19. Žirmūnai & 0.4402 & 0.5931 & 0.3385 & 0.4623 & 7 \\
\hline 20. Žvèrynas & 0.5652 & 0.7127 & 0.3887 & 0.6099 & 6 \\
\hline 21. Šnipiškès & 0.5737 & 0.0293 & 0.2725 & 0.1858 & 19 \\
\hline
\end{tabular}

Based on the EDAS results, overall, the Senamiestis neighborhood comes first, followed by Verkiai and then Naujamiestis. The analysis of the rankings according to different environments, however, shows that Naujamiestis ranked first according to the economic criteria, tenth according to the social criteria and fifth according to the environmental criteria. The MCDM methods are a way of assessing the impact of each environment on the overall result.

\section{The Assessment Results of the Vilnius Neighborhoods}

The application of multiple criteria assessment with COPRAS, SAW, TOPSIS and EDAS produces different priority rankings. The overall results were calculated using the rank average, Borda count and Copeland's methods [20,82-85]. Table 15 shows the priority rankings determined by COPRAS, SAW, TOPSIS and EDAS, plus the rank average, Borda count and Copeland's methods. 
Table 15. The priority rankings compared.

\begin{tabular}{|c|c|c|c|c|c|c|c|}
\hline & $\begin{array}{c}\text { COPRAS } \\
\text { Priority } \\
\text { Ranking }\end{array}$ & $\begin{array}{c}\text { SAW } \\
\text { Priority } \\
\text { Ranking }\end{array}$ & $\begin{array}{l}\text { TOPSIS } \\
\text { Priority } \\
\text { Ranking }\end{array}$ & $\begin{array}{c}\text { EDAS } \\
\text { Priority } \\
\text { Ranking }\end{array}$ & $\begin{array}{c}\text { Rank Average } \\
\text { Priority } \\
\text { Ranking }\end{array}$ & $\begin{array}{c}\text { Borda Count } \\
\text { Priority } \\
\text { Ranking }\end{array}$ & $\begin{array}{c}\text { Copeland's } \\
\text { Priority } \\
\text { Ranking }\end{array}$ \\
\hline Antakalnis & 5 & 5 & 6 & 4 & 4 & 4 & 4 \\
\hline Fabijoniškès & 9 & 9 & 11 & 10 & 10 & 10 & 10 \\
\hline Grigiškès & 20 & 20 & 20 & 20 & $20-21$ & $20-21$ & $20-21$ \\
\hline Justiniškès & 19 & 19 & 21 & 21 & $20-21$ & $20-21$ & $20-21$ \\
\hline Karoliniškès & 17 & 17 & 19 & 17 & 18 & 18 & 18 \\
\hline Lazdynai & 19 & 19 & 17 & 16 & 19 & 19 & 19 \\
\hline Naujamiestis & 3 & 3 & 2 & 3 & 2 & 2 & 2 \\
\hline Naujininkai & 13 & 13 & 13 & 18 & $14-15$ & $14-15$ & $14-15$ \\
\hline Naujoji Vilnia & 15 & 15 & 14 & 13 & $14-15$ & $14-15$ & $14-15$ \\
\hline Paneriai & 2 & 2 & 10 & 14 & 7 & $6-7$ & $6-7$ \\
\hline Pašilaičiai & 16 & 16 & 12 & 8 & 13 & 13 & 13 \\
\hline Pilaitè & 18 & 18 & 15 & 12 & 17 & 17 & 17 \\
\hline Rasos & 8 & 8 & 9 & 9 & 8 & 8 & 8 \\
\hline Senamiestis & 1 & 1 & 1 & 1 & 1 & 1 & 1 \\
\hline Šeškinė & 14 & 14 & 18 & 15 & 16 & 16 & 16 \\
\hline Verkiai & 4 & 4 & 3 & 2 & 3 & 3 & 3 \\
\hline Vilkpèdè & 6 & 6 & 5 & 5 & 5 & 5 & 5 \\
\hline Viršuliškès & 12 & 12 & 16 & 11 & 12 & 12 & 12 \\
\hline Žirmūnai & 11 & 11 & 8 & 7 & 9 & 9 & 9 \\
\hline Žvèrynas & 7 & 7 & 4 & 6 & 6 & $6-7$ & $6-7$ \\
\hline Šnipiškès & 10 & 10 & 7 & 19 & 11 & 11 & 11 \\
\hline
\end{tabular}

The calculations of the overall results show that the rank average, Borda count and Copeland's methods produce matching results. The assessment of 21 neighborhoods in Vilnius using COPRAS, SAW, TOPSIS and EDAS suggests that Senamiestis is the healthiest and safest neighborhood compared to the others with reference to the principles of sustainable development.

\section{Discussion and Conclusions}

This article aims to assess the built environment in view of the principles of sustainable development with a focus on a healthy and safe environment. Many multiple criteria analysis methods such as AHP, ELECTRE, TOPSIS, COPRAS and ANP can be applied to analyze a sustainable built environment. However, the results they produce for the same problem with identical criteria, values and weights are often different. In search of a more reliable tool, this study proposes that a system of MCDM methods should be applied to a single problem. COPRAS, SAW, TOPSIS and EDAS were used for the assessment of 21 neighborhoods in Vilnius. Their priority was ranked, and the results differed. The overall results were calculated using the rank average, Borda count and Copeland's method. The results for all three methods are identical, so the proposed system of MCDM methods could be applied for the assessment of a sustainable built environment. For future discussion, a developed criteria system of sustainable development with a focus on a healthy and safe environment could be extended by integrating cultural, ethical, psychological, religious, emotional and other dimensions, which are important for the creation of a sustainable community.

The assessment of a healthy and safe built environment leads to the following conclusions:

1. The literature analysis determined that the development of a healthy and safe built environment must rest on the key principles of sustainable development, i.e., the integration of the economic environment, the social environment and the environmental dimension.

2. A sustainable built environment is an inseparable component of sustainable community building. Communities should have hospitals, schools, green spaces, public transport and other facilities within easy reach. The community must feel safe and healthy. 
3. The assessment criteria for a healthy and safe built environment were classified according to the key principles of sustainable development. The economic environment and the social environment were assessed against five criteria; the environmental dimension was assessed against four criteria.

4. The objective weights of the criteria for a healthy and safe built environment were determined using the entropy, CILOS and IDOCRIW methods. The subjective weights were determined based on expert judgement, with 13 experts involved. All of the assessments produced concordance of opinion. The objective and subjective weights were integrated to produce the overall weights that ensure a more reliable assessment of the significance the criteria have in the context of sustainable development. According to overall criteria weights, price and population density play the biggest role in the assessment of a healthy and safe built environment in the economic environment. Out of the social environment criteria, the number of medical institutions and the crime rate have the biggest impact. An analysis of the environmental dimension criteria shows that green spaces and air pollution have the biggest impact on the assessments.

5. The Vilnius neighborhoods were assessed using the MCDM methods such as COPRAS, SAW, TOPSIS and EDAS. The calculations were a two-stage process. The Vilnius neighborhoods were assessed for each environment, and then, an overall assessment was made in the context of a healthy and safe built environment. The calculations show that the assessments of 21 neighborhoods in Vilnius based on economic, social and environmental criteria differ due to the different impact each environment has on the overall assessment results. In terms of the economic environment, Naujamiestis ranked the highest. In terms of the social environment and environmental protection, Senamiestis was rated the best.

6. The results for all three methods (the rank average, Borda count and Copeland's) are identical. It follows that Senamiestis is the healthiest and safest neighborhood compared to the others with reference to the principles of sustainable development.

Author Contributions: The individual contribution and responsibilities of the authors were as follows: Edmundas Kazimieras Zavadskas and Ieva Ubarte provided and designed the research concept and the purpose; Arturas Kaklauskas and Fausto Cavallaro provided extensive advice throughout the study, regarding the research design, methodology, findings and revised the manuscript; Valentinas Podvezko collected and analyzed the data. All the authors have read and approved the final manuscript.

Conflicts of Interest: The authors declare no conflict of interest.

\section{References}

1. Anderson, J.E.; Wulfhorst, G.; Lang, W. Energy analysis of the built environment-A review and outlook. Renew. Sustain. Energy Rev. 2015, 44, 149-158. [CrossRef]

2. Joffe, H.; Smith, N. City dweller aspirations for cities of the future: How do environmental and personal wellbeing feature? Cities 2016, 58, 102-112. [CrossRef]

3. Sallis, J.F.; Bull, F.; Burdett, R.; Frank, L.D.; Griffiths, P.; Giles-Coti, B.; Stevenson, M. Use of science to guide city planning policy and practice: How to achieve healthy and sustainable future cities. Lancet 2016, 388, 2936-2947. [CrossRef]

4. Mohtashami, N.; Mahdavinejad, M.; Bemanian, M. Contribution of City Prosperity to Decisions on Healthy Building Design: A case study of Tehran. Front. Archit. Res. 2016, 5, 319-331. [CrossRef]

5. Elwell, H.; Shulaker, B.; Rippon, J.; Wood, R. Strategic and integrated planning for healthy, connected cities: Chattanooga case study. Prev. Med. 2017, 95, S115-S119. [CrossRef] [PubMed]

6. Ren, Z.; Anumba, C.J.; Yang, F. Development of CDPM matrix for the measurement of collaborative design performance in construction. Autom. Constr. 2013, 32, 14-23. [CrossRef]

7. Walsh, C.J. Sustainable Climate Adaptation, the Critical Link between Sustainable Development \& Climate Change in the Built Environment. 2012. Available online: http://www.sustainable-design.ie/sustain/ CJWalsh-Paper_Sustainable-Adaptation_21-March-2010.pdf (accessed on 16 January 2016).

8. Huang, H.; Yin, L. Creating sustainable urban built environments: An application of hedonic house price models in Wuhan, China. J. Hous. Built Environ. 2015, 30, 219-235. [CrossRef] 
9. Barbosa, M.T.G.; Almeida, M. Developing the methodology for determining the relative weight of dimensions employed in sustainable building assessment tools for Brazil. Ecol. Indic. 2017, 73, 46-51. [CrossRef]

10. Diaz-Sarachaga, J.M.; Jato-Espino, D.; Alsulami, B.; Castro-Fresno, D. Evaluation of existing sustainable infrastructure rating systems for their application in developing countries. Ecol. Indic. 2016, 71, 491-502. [CrossRef]

11. Pérez-Ortiz, M.; de la Paz-Marín, M.; Gutiérrez, P.A.; Hervás-Martínez, C. Classification of EU countries' progress towards sustainable development based on ordinal regression techniques. Knowl.-Based Syst. 2014, 66, 178-189. [CrossRef]

12. Pupphachai, U.; Zuidema, C. Sustainability indicators: A tool to generate learning and adaptation in sustainable urban development. Ecol. Indic. 2017, 72, 784-793. [CrossRef]

13. Karaca, F.; Raven, P.G.; Machell, J.; Camci, F. A comparative analysis framework for assessing the sustainability of a combined water and energy infrastructure. Technol. Forecast. Soc. Chang. 2015, 90, 456-468. [CrossRef]

14. Mulliner, E.; Malys, N.; Maliene, V. Comparative analysis of MCDM methods for the assessment of sustainable housing affordability. Omega 2016, 59, 146-156. [CrossRef]

15. Nilashi, M.; Zakaria, R.; Ibrahim, O.; Majid, M.Z.A.; Zin, R.M.; Chugtai, M.W.; Abidin, N.I.Z.; Sahamir, S.R.; Yakubu, D.A. A knowledge-based expert system for assessing the performance level of green buildings. Knowl.-Based Syst. 2015, 86, 194-209. [CrossRef]

16. Chen, Z.; Abdullah, A.B.; Anumba, C.J.; Li, H. ANP Experiment for Demolition Plan Evaluation. J. Constr. Eng. Manag. 2014, 140. [CrossRef]

17. Dong, J.; Chi, Y.; Zou, D.; Fu, C.; Huang, Q.; Ni, M. Energy-environment-economy assessment of waste management systems from a life cycle perspective: Model development and case study. Appl. Energy 2014, 114, 400-408. [CrossRef]

18. Motuzienè, V.; Rogoža, A.; Lapinskeinè, V.; Vilutienė, T. Construction solutions for energy efficient single-family house based on its life cycle multi-criteria analysis: A case study. J. Clean. Prod. 2016, 112, 532-541. [CrossRef]

19. Xu, J.; Wand, Y.; Tao, Z. Rough approximation based strategy model between a green building developer and a contractor under a fuzzy environment. Knowl.-Based Syst. 2013, 46, 54-68. [CrossRef]

20. Hwang, C.-L.; Yoon, K. Multiple Attribute Decision Making. Methods and Applications: A State-of-the-Art Survey; Springer: Berlin/Heidelberg, Germany, 1981.

21. Ghorabaee, M.K.; Zavadskas, E.K.; Olfat, L.; Turskis, Z. Multi-criteria inventory classification using a new method of Evaluation based on Distance from Average Solution (EDAS). Informatica 2015, 26, 435-451. [CrossRef]

22. Zavadskas, E.K.; Kaklauskas, A.; Sarka, V. The new method of multicriteria complex proportional assessment of projects. Technol. Econ. Dev. Econ. 1994, 1, 131-139.

23. Siemens. The Green City Index, A Summary of the GREEN City Index Research Series. 2012. Available online: http://www.siemens.com/entry/cc/features/greencityindex_international/all/en/pdf/ gci_report_summary.pdf (accessed on 20 January 2016).

24. Mardani, A.; Jusoh, E.K.; Zavadskas, F.; Cavallaro, Z. Khalifah, Sustainable and Renewable Energy: An Overview of the Application of Multiple Criteria Decision Making Techniques and Approaches. Sustainability 2015, 7, 13947-13984. [CrossRef]

25. Kaklauskas, A.; Zavadskas, E.K. Decision support system for innovation with a special emphasis on pollution. Int. J. Environ. Pollut. 2007, 30, 518-528. [CrossRef]

26. Li, Y.; Cheng, H.; Beeton, R.J.S.; Sigler, T.; Halog, A. Sustainability from a Chinese cultural perspective: The implications of harmonious development in environmental management. Environ. Dev. Sustain. 2016, 13, 679-696. [CrossRef]

27. Watts, P.; Custer, B.; Yi, Z.F.; Ontiri, E.; Pajaro, M. A Yin-Yang approach to education policy regarding health and the environment: Early-careerists' image of the future and priority programmes. Nat. Resour. Forum 2015, 39, 202-213. [CrossRef]

28. Hashemkhani Zolfani, S.; Zavadskas, E.K.; Turskis, Z. Design of products with both international and local perspectives based on Yin-Yang balance theory and SWARA method. Ekonom. Istraz. Econ. Res. 2013, 22, 153-166. 
29. Medineckiene, M.; Zavadskas, E.K.; Bjork, F.; Turskis, Z. Multi-criteria decision-making system for sustainable building assessment/certification. Arch. Civil Mech. Eng. 2015, 11, 11-18. [CrossRef]

30. Wang, Y.H.; Deng, X.M.; Marcucci, D.J.; Le, Y.E. Sustainable Development Planning of Protected Areas near Cities: Case Study in China. J. Urban Plan. Dev.-Asce 2013, 132, 133-143. [CrossRef]

31. Si, J.; Marjanovic-Halburd, L.; Nasiri, F.; Bell, S. Assessment of building-integrated green technologies: A review and case study on applications of Multi-Criteria Decision Making (MCDM) method. Sustain. Cities Soc. 2016, 27, 106-115. [CrossRef]

32. Ignatius, J.; Rahman, A.; Yazdani, M.; Saparauskas, J.; Haron, S.H. An integrated fuzzy ANP-QFD approach for green building assessment. J. Civil Eng. Manag. 2016, 24, 551-563. [CrossRef]

33. Zhang, L.; Xu, Y.; Yeh, C.H.; Liu, Y.; Zhou, D.Q. City sustainability evaluation using multi-criteria decision making with objective weights of interdependent criteria. J. Clean. Prod. 2016, 131, 491-499. [CrossRef]

34. Zavadskas, E.K.; Kaklauskas, A. Model for Lithuanian construction industry development. Transform. Bus. Econ. 2008, 1, 152-168. [CrossRef]

35. Pourahmad, A.; Hosseini, A.; Banaitis, A.; Nasiri, H.; Banaitiene, N.; Tzeng, G.H. Combination of fuzzy-AHP and DEMATEL-ANP with GIS in a new hybrid MCDM model used for the selection of the best space for leisure in a blighted urban site. Technol. Econ. Dev. Econ. 2015, 25, 773-796. [CrossRef]

36. Liou, J.J.H. New concepts and trends of MCDM for tomorrow-In honor of professor Gwo-Hshiung Tzeng on the occasion of his 70th birthday. Technol. Econ. Dev. Econ. 2013, 12, 367-375. [CrossRef]

37. Cavallaro, F. Fuzzy TOPSIS approach for assessing thermal-energy storage in concentrated solar power (CSP) systems. Appl. Energy 2010, 87, 496-503. [CrossRef]

38. Cavallaro, F. Multi-criteria decision aid to assess concentrated solar thermal technologies. Renew. Energy 2009, 34, 1678-1685. [CrossRef]

39. Saaty, T.J.; Ergu, D. When is a Decision-Making Method Trustworthy? Criteria for Evaluating Multi-Criteria Decision-Making Methods. Int. J. Inform. Technol. Decis. Making 2015, 16, 1171-1187. [CrossRef]

40. Kou, G.; Ergu, D.; Lin, C.S.; Chen, Y. Pairwise comparison matrix in multiple criteria decision making. Technol. Econ. Dev. Econ. 2016, 25, 738-765. [CrossRef]

41. Antucheviciene, J.; Kou, G.; Maliene, V.; Vaidogas, E.R. Mathematical Models for Dealing with Risk in Engineering. Math. Probl. Eng. 2016, 2016, 1-3. [CrossRef]

42. Li, G.X.; Kou, G.; Peng, Y. Dynamic fuzzy multiple criteria decision making for performance evaluation. Technol. Econ. Dev. Econ. 2015, 25, 705-719. [CrossRef]

43. Kanapeckienè, L.; Kaklauskas, A.; Zavadskas, E.K.; Raslanas, S. Method and system for multi-attribute market value assessment in analysis of construction and retrofit projects. Expert Syst. Appl. 2011, 311, 14196-14207. [CrossRef]

44. Mardani, A.; Jusoh, K.M.D.; Nor, Z.; Khalifah, N.; Zakwan, A. Valipour, Multiple criteria decision-making techniques and their applications-A review of the literature from 2000 to 2014. Econ. Res.-Ekonom. Istraz. 2015, 21, 516-571. [CrossRef]

45. Tzeng, G.-H.; Huang, J.-J. Multiple Attribute Decision Making: Methods and Applications; CRC Press: Boca Raton, FL, USA, 2011.

46. Liou, J.H.J.; Tamošaitienè, J.; Zavadskas, E.K.; Tzeng, G.-H. New hybrid COPRAS-G MADM Model for improving and selecting suppliers in green supply chain management. Int. J. Prod. Res. 2016, 51, 114-134. [CrossRef]

47. Kaklauskas, A.; Zavadskas, E.K.; Lapinskeine, V.; Sliogeriene, J.; Gudauskas, R.; Raistenskis, J.; Cerkauskiene, R.; Jackute, I.; Kumzaite, S. Multiple-Criteria Analysis of Life Cycle of Energy-Efficient Built Environment. In Nearly Zero Energy Building Refurbishment: A Multidisciplinary Approach; Torgal, F.P., Mistretta, M., Kaklauskas, A., Granqvist, C.G., Cabeza, L.F., Eds.; Springer: London, UK, 2013; pp. $299-324$.

48. Keall, M.D.; Pierse, N.; Howden-Chapman, P.; Cunningham, C.; Cunningham, M.; Guria, J.; Baker, M.G. Home modifications to reduce injuries from falls in the Home Injury Prevention Intervention (HIPI) study: A cluster-randomised controlled trial. Lancet 2015, 385, 231-238. [CrossRef]

49. Keall, M.D.; Howden-Chapman, P.; Baker, M.G.; Kamalesh, V.; Cunningham, M.; Cunningham, C.; Guria, J.; Draper, R.; Skelton, P. Formulating a programme of repairs to structural home injury hazards in New Zealand. Accid. Anal. Prev. 2013, 57, 124-130. [CrossRef] [PubMed]

50. Viteikiene, M.; Zavadskas, E.K. Evaluating the Sustainability of Vilnius City Residential Areas. J. Civ. Eng. Manag. 2007, 2, 149-155. 
51. Dempsey, N.; Brown, C.; Bramley, G. The key to sustainable urban development in UK cities? The influence of density on social sustainability. Prog. Plan. 2012, 73, 89-141. [CrossRef]

52. Maliene, V.; Malys, N. High-quality housing-A key issue in delivering sustainable communities. Build. Environ. 2009, 42, 426-430. [CrossRef]

53. Ceccato, V.; Lukyte, N. Safety and sustainability in a city in transition: The case of Vilnius, Lithuania. Cities 2011, 28, 83-94. [CrossRef]

54. Lee, Y.; Lim, S.; Kim, G. Improvement characteristics shown in holistic regeneration of Ballymun toward sustainable community. Build. Environ. 2010, 45, 279-286. [CrossRef]

55. IPH Action Areas in Health Inequalities-Developing Healthy and Sustainable Communities. 2010. Available online: http:/ /iph.ie/healthinequalities/healthylivingenvironments (accessed on 6 March 2015).

56. Lotteau, M.; Loubet, P.; Pousse, M.; Dufrasnes, E.; Sonnemann, G. Critical review of life cycle assessment (LCA) for the built environment at the neighborhood scale. Build. Environ. 2015, 93, 165-178. [CrossRef]

57. Mulliner, E.; Smallbone, K.; Maliene, V. An assessment of sustainable housing affordability using a multiple criteria decision making method. Omega 2013, 41, 270-279. [CrossRef]

58. Sohn, D.-W. Residential crimes and neighbourhood built environment: Assessing the effectiveness of crime prevention through environmental design (CPTED). Cities 2016, 52, 86-93. [CrossRef]

59. Charoenkit, S.; Kumar, S. Environmental sustainability assessment tools for low carbon and climate resilient low income housing settlements. Renew. Sustain. Energy Rev. 2014, 38, 509-525. [CrossRef]

60. Conejos, S.; Langston, C.; Smith, J. AdaptSTAR model: A climate-friendly strategy to promote built environment sustainability. Habitat Int. 2013, 37, 95-103. [CrossRef]

61. Conejos, S.; Langston, C.; Smith, J. Designing for better building adaptability: A comparison of adaptSTAR and ARP models. Habitat Int. 2014, 41, 85-91. [CrossRef]

62. Cozens, P. Crime prevention through environmental design in Western Australia: Planning for sustainable urban futures. Int. J. Sustain. Dev. Plan. 2008, 3, 272-292. [CrossRef]

63. Arni, A.G.; Khairil, W.A. Promoting Collaboration between Local Community and Park Management towards Sustainable Outdoor Recreation. Proc. Soc. Behav. Sci. 2013, 91, 57-65. [CrossRef]

64. Chan, E.; Lee, G.K.L. Critical factors for improving social sustainability of urban renewal projects. Soc. Indic. Res. 2008, 82, 243-256. [CrossRef]

65. Deng, Y.; Li, Z.; Quigley, J.M. Economic returns to energy-efficient investments in the housing market: Evidence from Singapore. Reg. Sci. Urban Econ. 2012, 43, 506-515. [CrossRef]

66. El Asmar, J.-P.; Taki, A.H. Sustainable rehabilitation of the built environment in Lebanon. Sustain. Cities Soc. 2014, 10, 22-38. [CrossRef]

67. Fitzgerald, B.G.; O'Doherty, T.; Moles, R.; O’Regan, B. A quantitative method for the evaluation of policies to enhance urban sustainability. Ecol. Indic. 2012, 18, 371-378. [CrossRef]

68. Lamķquiz, P.J.; López-Domķnguez, J. Effects of built environment on walking at the neighbourhood scale. A new role for street networks by modelling their configurational accessibility? Transp. Res. 2015, 74, 148-163. [CrossRef]

69. Nuuter, T.; Lill, I.; Tupenaite, L. Comparison of housing market sustainability in European countries based on multiple criteria assessment. Land Use Policy 2015, 42, 642-651. [CrossRef]

70. Oltean-Dumbrava, C.; Watts, G.; Miah, A. Transport infrastructure: Making more sustainable decisions for noise reduction. J. Clean. Prod. 2013, 42, 58-68. [CrossRef]

71. Sun, X.; Liu, X.; Li, F.; Tao, Y.; Song, Y. Comprehensive evaluation of different scale cities' sustainable development for economy, society, and ecological infrastructure in China. J. Clean. Prod. 2015. [CrossRef]

72. Xing, Y.; Horner, R.M.W.; El-Hamar, M.A.; Bebbington, J. A framework model for assessing sustainability impacts of urban development. Account. Forum 2009, 33, 209-224. [CrossRef]

73. Yin, Y.; Mizokami, S.; Aikawa, K. Compact development and energy consumption: Scenario analysis of urban structures based on behavior simulation. Appl. Energy 2015, 159, 449-457. [CrossRef]

74. ERABUILD. State-of-the-Art of Benchmarking in Construction and Real Estate-Developing Indicators for Transparency. CREDIT Report 1; Project Application; Danish Building Research Institute: Aalborg, Denmark, 2007.

75. Lazauskaitė, D.; Burinskienè, M.; Podvezko, V. Subjectively and objectively integrated assessment of the quality indices of the suburban residential environment. Int. J. Strat. Property Manag. 2015, 19, 297-308. [CrossRef] 
76. Zavadskas, E.K.; Podvezko, V. Integrated determination of objective criteria weights in MCDM. Int. J. Inform. Technol. Decis. Making 2016, 12, 267-283. [CrossRef]

77. Kurilov, J.; Vinogradova, I.; Kubilinskienè, S. New MCEQLS fuzzy AHP methodology for evaluating learning repositories: A tool for technological development of economy. Technol. Econ. Dev. Econ. 2016, 21, 142-155. [CrossRef]

78. Shannon, C.E. A mathematical theory of communication. Bell Syst. Tech. J. 1948, 27, 379-423. [CrossRef]

79. Cavallaro, F.; Zavadskas, E.K.; Raslanas, S. Evaluation of Combined Heat and Power (CHP) Systems Using Fuzzy Shannon Entropy and Fuzzy TOPSIS. Sustainability 2016, 8, 556. [CrossRef]

80. Mirkin, B. Problema Grupovogo Vibora; Halsted Press: Moskva, Russia, 1974.

81. MacCrimmon, K.R. Decision Making among Multiple-Attribute Alternatives: Survey and Consolidated Approach. RAND Memorandum; Rand Corporation: St. Monica, CA, USA, 1968.

82. Borda, J.C. Memoire sur les Elections au Scrutiny; Histoire de l'Academie Royale des Sciences: Paris, France, 1781.

83. McLean, I. The Borda and Condorcet principles: Three medieval applications. Soc. Choice Welf. 1990, 2, 99-108. [CrossRef]

84. Erlandson, R. System Evaluation Methodologies: Combined Multi-dimensional Scaling and Ordering Techniques. IEEE Trans. Syst. Man Cybern. 1978, 6, 421-432. [CrossRef]

85. Fishburn, P. A Comparative Analyses of Group Decision Methods. Behav. Sci. 1971, 16, 538-544. [CrossRef]

86. Kendall, M. Rank Correlation Methods; Griffin: London, UK, 1975.

(C) 2017 by the authors. Licensee MDPI, Basel, Switzerland. This article is an open access article distributed under the terms and conditions of the Creative Commons Attribution (CC BY) license (http:/ / creativecommons.org/licenses/by/4.0/). 